\title{
When Harmonization is Not Enough: Shareholder Stewardship in the European Union
}

\author{
Dionysia Katelouzou ${ }^{1}$ D $\cdot$ Konstantinos Sergakis $^{2}$ (D)
}

Published online: 1 February 2021

(C) The Author(s) 2021

\begin{abstract}
On 10 June 2019 the transposition and implementation deadline for the shareholder engagement rules imposed upon institutional investors and asset managers by the revised Shareholder Rights Directive (SRD II) expired. This article offers an original account of the rationale, the dynamics and the evolution of this EU-driven policy, which aims to promote long-term institutional shareholder engagement within (or in the absence of) nationally embedded frameworks. We place the SRD II shareholder engagement rules within what we see as a multi-layered regulatory landscape consisting in some Member States of soft-law stewardship codes or similar principles and guidelines, and we find-perhaps surprisingly-that the SRD II stewardshiprelated provisions were transposed in a literal and minimalistic fashion without any customization to divergent national specifications and despite the fact that the SRD II is only a minimum harmonization directive. We search for explanations for this transposition pattern by pointing to three key issues: the policy and institutional misfit between the harmonized rules and national regimes, the lack of a strong market demand for shareholder stewardship, and the more apt soft, flexible and mostly bottom-up norms (contained in codes or similar principles and guidelines) -rather than (semi-)hard top-down rules-in inculcating good shareholder stewardship practices. Against this background of minimalist intervention (both at the EU and national levels), we find that pre-SRD II soft stewardship initiatives have had two key positive effects. First, they increased market actors' familiarity and preparedness with the SRD II transposed rules, thereby increasing the likelihood of effective compliance with good shareholder stewardship standards whilst maintaining national idiosyncrasies. Second, soft-law stewardship codes or similar principles and guidelines, despite their own weaknesses, are vital mechanisms of innovative norm-generation and can expand or adjust the SRD II stewardship-related rules to provide tailored shareholder stewardship frameworks and serve as a signalling function for key market actors. From this it follows that the uniform, but minimalistic, transposition of the SRD II stewardship-related rules across the EU, although welcome in shaping the minimum standards, needs to be supported by tailored, soft-law stewardship codes or similar principles and guidelines. Such a symbiosis of the harmonized SRD
\end{abstract}

Extended author information available on the last page of the article 
II shareholder engagement rules and supporting soft-law stewardship developments will allow the tailoring of shareholder stewardship norms to local conditions and the provision of guidance and meaning to the SRD II rules, while a minimum harmonization of shareholder stewardship is already secured.

Keywords Revised shareholder rights directive $\cdot$ Institutional investors · Shareholder engagement $\cdot$ Shareholder stewardship $\cdot$ Minimum harmonization $\cdot$ Soft law

\section{Introduction}

'We have learned the lessons from the past. With the revised Shareholder Rights Directive we pave the way to responsible investment and corporate decisions that have a longer time horizon, instead of focusing on short-term financial gain', said Věra Jourová, Commissioner for Justice, Consumers and Gender Equality, in June $2019,{ }^{1}$ three days before the expiry of the transposition deadline of the revised Shareholder Rights Directive (SRD II). ${ }^{2}$ In this article we deconstruct this statement in light of the complexities of transforming the EU aspirations relating to the 'long-term' and 'responsible' corporate governance role of institutional shareholders (asset owners and asset managers) to concrete and workable national shareholder engagement and broader shareholder stewardship practices. Similar to Katelouzou, we use the term 'shareholder stewardship' as broader than that of 'shareholder engagement'. 3 The former encompasses not only informal and formal shareholder engagement and the monitoring of investee companies (such as conducting a meaningful dialogue with investee companies and exercising voting rights), but also related disclosure requirements imposed upon institutional investors and asset managers, such as in relation to conflicts of interests. ${ }^{4}$

Previous contributions have already pointed out not only the rather fractional alignment between the 'stewardship ideal' and the business models of the investment fund industry, ${ }^{5}$ but also the enforcement weaknesses of current shareholder stewardship frameworks. ${ }^{6}$ What is less discussed, however, are the practical

\footnotetext{
1 See European Commission, Daily News, 7 June 2019, https://ec.europa.eu/commission/presscorner/ detail/en/MEX_19_2913. Accessed 4 December 2019.

2 Directive 2017/828/EU of the European Parliament and of the Council of 17 May 2017 amending Directive 2007/36/EC as regards the encouragement of long-term shareholder engagement [2017] OJ L 132/1. The SRD II transposition and implementation deadline expired on 10 June 2019, apart from Art. $3 \mathrm{a}, 3 \mathrm{~b}$ and $3 \mathrm{c}$ for which the Commission Implementing Regulation set the implementation deadline on 4 September 2020. See Commission Implementing Regulation (EU) 2018/1212 of 3 September 2018 laying down minimum requirements implementing the provisions of Directive 2007/36/EC of the European Parliament and of the Council as regards shareholder identification, the transmission of information and the facilitation of the exercise of shareholder rights [2018] OJ L 223/1.

3 This term is borrowed from Katelouzou (2021) who provides a comprehensive analysis of the broader concept of stewardship and its corporate governance as well as investment management aspects.

4 Ibid.

5 See Barker and Chiu (2017).

6 See Katelouzou and Sergakis (2020) who introduce an enforcement taxonomy for stewardship.
} 
challenges faced by legislators, public or quasi-public and private standard-setters, EU and national alike, in stirring institutional investors towards shareholder stewardship policies and practices. This is due to the heterogeneous shareholder stewardship policies and engagement modes at the EU and national levels that create what can be described as a multi-layered regulatory shareholder stewardship landscape in Europe. This is what this article aims to elucidate and evaluate.

On the one hand, Article $3 \mathrm{~g}$ of the SRD II juridifies certain aspects of shareholder stewardship imposing requirements on institutional investors and asset managers to develop and publish an engagement policy. The SRD II was issued to ensure minimum standards of shareholder engagement, as a 'floor' rather than a 'ceiling' upon which the Member States may set superior standards. ${ }^{7}$ Yet, on the other hand, we find that the SRD II stewardship-related provisions are "transposed" ${ }^{8}$ in a literal and minimalistic manner. While from an EU-compliance perspective this is not a major concern as a literal transposition appears to be in line with the wording and spirit of the directive, we question the lack of national deviations within the boundaries allowed by the European Commission. In other words, we ask whether the lack of any "customization" ${ }^{9}$ within the scope of the discretion granted by the SRD II can be justified in light of pre-SRD II rules setting the shareholder stewardship framework at the national level and the cross-country differences in market structures and cultural traditions. Two observations are made in this regard. First, in some Member States we find soft-law stewardship 'codes' (in the form of fully-fledged codes or preliminary initiatives and guidelines $)^{10}$ that are more closely aligned with national specific (institutional or political) situations, traditions and existing laws. Such softlaw stewardship codes along with other stewardship-related principles and guidelines found in corporate governance codes or investor associations' codes of conduct can, in our opinion, offer a distinctive normative framework that will complement, rather than substitute, the SRD II stewardship-related rules and nudge market actors towards meaningful and tailored shareholder stewardship practices. This is due to the capacity of such soft-law shareholder stewardship developments to provide dynamic, flexible, innovative and tailored norm-generation and increase familiarity and compliance with the SRD II rules, attributes that make them particularly attractive to market actors and have the potential to boost 'market demand'11 for shareholder stewardship.

Our support for soft law in the area of shareholder stewardship may, at first glance, appear to be unusual and unsympathetic to the supporters of the Fullerian

\footnotetext{
7 See also Katelouzou (2021).

${ }^{8}$ In this article we look at the 'formal' transposition not the 'implementation' of SRD II. We therefore do not look at the practical implementation or monitoring of the SRD II transposed provisions by Member States.

9 For the distinction between 'customization' and 'non-compliance' see Thomann (2015).

${ }^{10}$ We use the term 'code' broadly in this study as encompassing both stewardship codes (that is the case in the UK, the Netherlands and Denmark) as well as preliminary initiatives (that is the case in Italy, Norway, Switzerland). For the distinction between fully-fledged stewardship codes and preliminary stewardship initiatives, see Katelouzou and Siems (2021).

11 On the demand side of stewardship see Katelouzou and Micheler (2021).
} 
conception of EU law-making described as 'one that sees the function of law as the provision of stable normative expectations'. ${ }^{12}$ Soft law, with its flexibility, variation and adaptability, has admittedly a low capacity for creating stable normative expectations. But, in our opinion, soft-law shareholder stewardship codes or similar principles and guidelines, despite their shortcomings, have already functioned as a normative-yet embryonic_- 'laboratory' offering educative and informational benefits to market actors as well as increasing familiarity with SRD II rules. The utility of such soft-law codes and principles/guidelines is even more significant in instances of the literal and minimalistic transposition of EU harmonized rules, ${ }^{13}$ as is the case with the SRD II stewardship-related rules. In such cases the normative gap created (in the absence of pre-existing national soft-law stewardship regimes) is considerable and market actors may not be gradually nudged towards meaningful shareholder stewardship; instead, they may risk perceiving the SRD II transposed rules as another compliance burden. With further harmonization in this area of law being unlikely, ${ }^{14}$ such a gap can only be bridged with the multiplication of soft-law stewardship frameworks by (quasi-)public regulators or private standard setters. Soft-law stewardship codes or similar principles and guidelines have already been successful mechanisms of innovative and customized norm-generation, expanding or adjusting the SRD II stewardship-related rules to specific legal, market or institutional (cultural) circumstances. Further, national regulators need to be mindful of the EU political drive for a quick fix of the shareholder engagement agenda within the investment chain and need to favour an organic growth of the 'stewardship market', ${ }^{15}$ instead of aiming to serve formalistically the EU vision of long-term shareholder engagement and stewardship through a literal and minimalistic transposition of the SRD II stewardship-related rules. Not only should soft-law rules relating to shareholder stewardship not be jettisoned after the transposition of SRD II, but also the multiplication of such initiatives in Member States with no pre-existing stewardship norms by (quasi-)public or private actors is both politically feasible and normatively desirable.

The remainder of the article proceeds as follows. Section 2 lays out what can be described as a multifaceted shareholder stewardship landscape in the EU. We first examine the EU aspirations that shaped the shareholder engagement policy agenda on the basis of the general criticism of the investor-alleged acquiescence to serious corporate governance shortcomings that contributed to the global financial crisis, and the ensuing SRD II rules juridifying shareholder stewardship. We then examine some of the key pre-SRD II soft-law initiatives, in the form of stewardship codes or principles/guidelines, that have been nudging actors towards the adoption of sound

\footnotetext{
12 Dawson (2009).

13 For an overview of the broader debate on EC-related implementation research in the area of social policy, see Falkner et al. (2005).

14 On the 'fight' over the EU Commission's Draft Shareholder Rights Directive 2014, see Hopt (2015), pp 139-213. As a more general observation, the harmonisation of company law has never been an easy task. See, for instance, Cioffi (2002), p 355 (illustrating the politics of the long process of debating and amending the 13th Directive on Takeover Bids).

15 On the demand and supply side of this market see Katelouzou (2021).
} 
stewardship practices independently from EU aspirations. We proceed our analysis by shedding light on the legal, market and cultural specificities within which this emerging multifaceted shareholder stewardship regulatory framework is embedded.

Section 3 illustrates how Member States transposed the SRD II shareholder-stewardship rules. Surprisingly, perhaps, we demonstrate a so far literal and minimalistic transposition of the SRD II rules irrespective of the pre-existence of national stewardship codes. We explain this unexpected and seemingly counterintuitive finding in light of the following factors: the novelty and ensuing lack of familiarity with the shareholder stewardship obligations in Member States with no pre-SRD II norms (policy misfit), the lack of a local market demand for a tailored transposition, and the more apt soft, flexible and mostly bottom-up rules (rather than semi-hard topdown rules) in inculcating good shareholder stewardship practices.

In Sect. 4 we expand this latter assertion and we argue that in the specific context of the SRD II the pre-existence of soft stewardship codes or similar principles and guidelines has had three additional positive effects. First, soft-law stewardship codes increased market actors' familiarity with and preparedness for the SRD II transposed rules, thereby increasing the likelihood of effective compliance with good shareholder stewardship standards whilst maintaining national idiosyncrasies. Second, soft-law codes serve a signalling function for other market actors, thereby increasing their legitimacy. Finally, soft-law stewardship codes are innovative norm-generating mechanisms and can expand or adjust the SRD II-related rules to provide tailored shareholder stewardship frameworks. From this it follows that the uniform, but minimalistic, transposition of the SRD II stewardship-related rules across the EU, although welcome in shaping the minimum standards, needs to be supported by tailored, soft-law stewardship codes or principles/guidelines. Such a symbiosis of the harmonized SRD II shareholder engagement rules and supporting soft-law stewardship developments will allow the customization of shareholder stewardship norms to local conditions and the provision of guidance and meaning to the SRD II rules, while a minimum harmonization of shareholder stewardship is already secured.

Section 5 concludes this article by reiterating the main claim for a multi-layered, symbiotic "regulatory space" ${ }^{16}$ for shareholder stewardship norms. The minimum standards introduced by the SRD II should be supported and advanced via soft-law shareholder stewardship norms. Such soft-law norms can be generated by different standard-setters (public and quasi-public regulators and private standard setters, national and supranational alike) and through different channels (stewardship codes or principles and guidelines or any other related initiative included in corporate governance codes, best practice standards or codes of conduct). In such a multi-layered regulatory space, shareholder stewardship norms - irrespective of their soft- or hardlaw nature and the form of responsibility they generate-should come together in a symbiotic and mutually supporting fashion to shape sound and meaningful shareholder stewardship standards and practices.

16 Scott (2001a); Hancher and Moran (1989). 


\section{The Regulatory Landscape of Shareholder Stewardship in Europe}

\subsection{The EU Aspirations: The Case of the SRD II}

Shareholder rights have been a key focus of the EU corporate governance regulatory architecture from its inception. ${ }^{17}$ Following the global financial crisis in 2007-2008 the case for a 'shareholder democracy' 18 energetically revived. Shareholder engagement was positively brought forward as a sound corporate governance attribute and soon became one of the key buzzwords in the EU context, along with an emphasis on long termism, transparency and more recently sustainability. In 2014, the European Commission proposed amendments to the 2007 Shareholder Rights Directive (SRD I), aiming, among other things, at improving corporate governance through the promotion of effective and sustainable shareholder engagement and the improvement of transparency along the investment chain. ${ }^{19}$ After various negotiations and consultations, ${ }^{20}$ the amended Directive (SRD II) was adopted in May 2017.

The SRD II recognizes that 'effective and sustainable shareholder engagement is one of the cornerstones of the corporate governance model of listed companies, which depends on checks and balances between the different organs and different stakeholders', ${ }^{21}$ and includes various measures with the aim of encouraging longterm shareholder engagement, such as facilitating the transmission of cross-border information and shareholder voting, ${ }^{22}$ improving the level and quality of the engagement of institutional investors and asset managers, ${ }^{23}$ enhancing the transparency of and shareholder influence on executive remuneration and related party transactions, ${ }^{24}$ and ensuring the reliability and quality of proxy advisers' recommendations. ${ }^{25}$ Even though the term 'stewardship' is used only once in the SRD II, the engagement and disclosure obligations imposed under Article $3 \mathrm{~g}$ are along lines that are similar to those in pre-existing national stewardship codes. ${ }^{26}$ Under Article $3 \mathrm{~g}$ institutional

\footnotetext{
17 See European Commission, 'Implementing the Framework for Financial Markets: Action Plan', Brussels, 11 May 1999, COM(1999) 232 final.

18 European Commission, 'Modernising Company Law and Enhancing Corporate Governance in the European Union-A Plan to Move Forwards in Brussels', 21 May 2003, COM(2003) 284 final.

19 Proposal for a Directive of the European Parliament and of the Council amending Directive 2007/36/ $\mathrm{EC}$ as regards the encouragement of long long-term shareholder engagement and Directive 2013/34/EU as regards certain elements of the corporate governance statement ( $\operatorname{SWD}(2014) 126,127,128$ final) published 9 April 2014.

${ }^{20}$ See specifically the Amendments adopted by the European Parliament on 8 July 2015 on the proposal for a directive of the European Parliament and of the Council amending Directive 2007/36/EC as regards the encouragement of long-term shareholder engagement and Directive 2013/34/EU as regards certain elements of the corporate governance statement, COM(2014)0213 — C7-0147/2014—2014/0121(COD).

21 SRD II, Recital 14.

22 SRD II, Arts. 3a-3d.

23 SRD II, Arts. 3g-3k.

24 SRD II, Arts. 9a-9c.

25 SRD II, Art. 3j.

26 SRD II, Recital 19: 'A medium to long-term approach is a key enable of responsible stewardship of assets'. See also European Commission, MEMO, 'Action Plan on European company law and corporate governance: Frequently Asked Questions', 12 December 2012, https://ec.europa.eu/commission/press
} 
investors (defined as insurance companies and pension funds) ${ }^{27}$ and asset managers ${ }^{28}$ are expected to develop an engagement policy, which would describe, among other things, how shareholder engagement is integrated in their investment strategy, how the financial and non-financial performance of investee companies are monitored, how dialogue is conducted, how voting rights are exercised, how other shareholders or stakeholders have been engaged and how actual and potential conflicts of interests are managed. ${ }^{29}$ This engagement policy along with its implementation need to be annually disclosed. ${ }^{30}$ The requirements relating to the establishment and disclosure of an engagement policy operate on a 'comply-or-explain' basis. ${ }^{31}$ The degree of flexibility offered by the 'comply-or-explain' principle is considerable and not uncommon in EU company law and corporate governance. ${ }^{32}$ Such 'opt-outs', ${ }^{33}$ despite their

\section{Footnote 26 (continued)}

corner/detail/en/MEMO_12_972) where the European Commission uses the term stewardship as synonymous to shareholder engagement. Accessed 4 December 2019.

${ }^{27}$ Pursuant to Art.1(2)(e) of the 2017 SRD, an institutional investor denotes '(i) an undertaking carrying out activities of life assurance within the meaning of points (a), (b) and (c) of Article 2(3) of Directive 2009/138/EC of the European Parliament and of the Council, and of reinsurance as defined in point (7) of Article 13 of that Directive provided that those activities cover life-insurance obligations, and which is not excluded pursuant to that Directive; (ii) an institution for occupational retirement provision falling within the scope of Directive (EU) 2016/2341 of the European Parliament and of the Council in accordance with Article 2 thereof, unless a Member State has chosen not to apply that Directive in whole or in parts to that institution in accordance with Article 5 of that Directive'.

${ }^{28}$ As defined in Art. 1(2)(f) of the 2017 SRD: 'an investment firm as defined in point (1) of Article 4(1) of Directive 2014/65/EU that provides portfolio management services to investors, an AIFM (alternative investment fund manager) as defined in point (b) of Article 4(1) of Directive 2011/61/EU that does not fulfil the conditions for an exemption in accordance with Article 3 of that Directive or a management company as defined in point (b) of Article 2(1) of Directive 2009/65/EC, or an investment company that is authorised in accordance with Directive 2009/65/EC provided that it has not designated a management company authorised under that Directive for its management'.

${ }^{29}$ SRD II, Art. $3 g(1)(a)$.

${ }^{30}$ SRD II, Art. 3g(1)(b). Additionally, institutional investors and asset managers are expected under Arts. $3 \mathrm{~h}$ and $3 \mathrm{i}$ to disclose annually their investment strategies (including how their investment strategy contributes to the medium to long-term performance of their assets) and their arrangements with each other. Even though these articles support shareholder engagement and shareholder stewardship, they relate to investment management aspects and therefore remain outside the scope of this study. Further on the investment management side of stewardship, see Katelouzou (2021).

${ }^{31}$ SRD II, Art. 3g(1).

${ }^{32}$ See, for example, Art. 46a of the 4th company law Directive 2006/46/EC of the European Parliament and of the Council of 14 June 2006 amending Council Directives 78/660/EEC on the annual accounts of certain types of companies, 83/349/EEC on consolidated accounts, 86/635/EEC on the annual accounts and consolidated accounts of banks and other financial institutions and 91/674/EEC on the annual accounts and consolidated accounts of insurance undertakings [2006] OJ L 224/1; Art. 20(1) of Directive 2013/34/EU of the European Parliament and the Council of 26 June 2013 on the annual financial statements, consolidated financial statements and related reports of certain types of undertakings, amending Directive 2006/43/EC of the European Parliament and of the Council and repealing Council Directives 78/660/EEC and 83/349/EEC [2013] OJ L 182/19. Both Directives adopt the 'comply-or-explain' principle for corporate governance statements of listed companies, allowing for different company law frameworks and governance systems to co-exist harmoniously while allowing for information to be disclosed across the EU.

${ }^{33}$ For the general debate on optional versus mandatory EU company law, see Hertig and McCahery (2006), pp 341-362. 
'softening' effect on EU law-making, decrease the risks of inefficient deadlocks and 'one size fits all' approaches that simply equalize standards 'from above'. Yet, the SRD II is not far from imposing a 'duty to demonstrate engagement ${ }^{34}$ on grounds of public interest relating to sustainable, long-term shareholder behaviour. ${ }^{35}$ Although this is not an expressly defined duty, the disclosure obligations imposed upon institutional investors and asset managers under Article $3 \mathrm{~g}$ compel that certain institutional shareholder engagement needs to be undertaken. This is arguably a move towards 'hardening' ${ }^{36}$ shareholder stewardship norms in contrast to national stewardship codes and principles which mainly treat shareholder stewardship as a voluntary practice. $^{37}$

But why did the EU regulators become increasingly focused on promoting shareholder engagement, especially on the part of institutional investors and asset managers? The politics of EU corporate governance regulation are well discussed. Laura Horn has forcefully pointed out that the primacy of shareholder rights found in the EU corporate governance regulation is not only a legal but also a political device. ${ }^{38}$ The EU emphasis on strengthening the rights of shareholders has been part of a broader movement from harmonization to marketization, cross-listings and the raising of capital and from industrial to shareholder democracy. ${ }^{39}$ But following the financial crisis of 2007-8 an important shift has begun to make inroads in the EU corporate governance regulation, a shift that has elsewhere been termed as a 'modified, sustainable, version of shareholder primacy'. SRD II is clearly a part of this movement. $^{40}$

The impetus of this reform was driven by strong criticism of the way institutional investors have undertaken their corporate governance roles over the years preceding and following the global financial crisis of 2007-2008 and of the general priority that has been given to them by policymakers compared to other corporate actors and wider stakeholders. Among the key claims that have been put forward is that investment management has largely supported or acquiesced to a short-term focus and has pressured executives to focus on current earnings, especially in financial institutions, at the expense of financial stability and long-term sustainability. ${ }^{41}$ The post-financial

\footnotetext{
${ }_{34}$ On the hardening of stewardship norms, see further Chiu and Katelouzou (2017), p 131.

35 For an overview of the growing public interest in stewardship codes, see Katelouzou (2019a), pp 581595.

36 Chiu and Katelouzou (2017). This hardening of stewardship norms is likely to be reinforced by the proposed disclosure obligations aiming to integrate environment, social and governance (ESG) considerations into the decision-making processes of institutional investors and asset managers. See European Commission, Proposal for a regulation of the European Parliament and of the Council on disclosures relating to sustainable investments and sustainability risks and amending Directive (EU) 2016/2341, $\operatorname{COM}(2018) 354$ final.

37 See Sect. 2.2 below.

38 Horn (2011).

39 Ibid.

40 For the regulatory transformation of shareholder rights and engagement in the EU, see, further, Katelouzou (2019b).

41 See European Commission, 'Green Paper: Corporate Governance in Financial Institutions and Remuneration Policies', Brussels, 2 June 2010, COM(2010) 284 final; European Commission, 'Green Paper: The EU Corporate Governance Framework', Brussels, 5 April 2011, COM(2011) 164 final.
} 
crisis environment also revealed the loss of investment incurred by ultimate beneficiaries-future retirees and long-term individual savers-rendering investment management a highly sensitive issue in the eyes of governments. ${ }^{42}$ The EU political stance on the agenda of long-term shareholder engagement has been clear since its inception: in a 'capital market regulation' facet, ${ }^{43}$ the SRD II imposes a top-down premise that nudging institutional investors and asset managers toward shareholder engagement and introducing greater disclosure requirements along the investment chain will generate sustainable shareholder value. ${ }^{44}$ This stance is a clear manifestation that the 'absentee landlord' 45 modus operandi can no longer be accepted as the default policy approach. But more importantly, as Katelouzou points out, the SRD II is moving away from an exclusive focus on shareholder primacy and the popular agency theory jargon towards a modified, enlightened, version of shareholder primacy and a sustainability lexicon. ${ }^{46}$

The role of the European Parliament has been instrumental in this regard. In July 2015 the European Parliament amended the original European Commission's SRD II proposal adding the reduction of social and environmental risks as key components of the engagement policy, compelling institutional investors to take into account and cooperate with stakeholders when engaging with investee companies, and 'socialising' the transparency requirements across the investment chain. ${ }^{47}$ These changes reflect the public interest in making institutional shareholders accountable to their clients, other market actors, investee companies and society at large. ${ }^{48}$ More recently shareholder stewardship has been placed as one of the key building blocks for an EU sustainable finance strategy. ${ }^{49}$ In the transition to a sustainable economy, institutional investors have an important stewardship role to play to manage company-specific risks, promote long-term performance and achieve sustainability in investment. ${ }^{50}$

\footnotetext{
42 On the impact of this change to 'the politically contested modification of institutional investors', see Kallifatides and Nachemson-Ekwall (2016), pp 278-294.

${ }^{43}$ For a critical approach, see Pacces (2018), p 523.

44 SRD II, Recitals 14-23.

45 Myners (2009), para. 38.

${ }^{46}$ Katelouzou (2019b).

${ }^{47}$ Amendments adopted by the European Parliament on 8 July 2015 on the proposal for a directive of the European Parliament and of the Council amending Directive 2007/36/EC as regards the encouragement of long-term shareholder engagement and Directive 2013/34/EU as regards certain elements of the corporate governance statement (COM(2014)0213-C7-0147/2014-2014/0121(COD)), https://www.europarl.europa.eu/sides/getDoc.do?pubRef=-//EP//TEXT+TA+P8-TA-20150257+0+DOC+XML+V0//EN. Accessed 4 December 2019.

${ }^{48}$ Chiu and Katelouzou (2017); Katelouzou (2019a).

${ }^{49}$ European Commission, 'Action Plan: Financing Sustainable Growth', Brussels, 8 March 2018, $\operatorname{COM}(2018) 97$ final, https://eur-lex.europa.eu/legal-content/EN/TXT/HTML/?uri=CELEX:52018 DC0097\&from=EN. Accessed 4 December 2019.

${ }^{50}$ Further on how stewardship can support sustainable finance, see Katelouzou and Klettner (2021).
} 
However, the chances of institutional shareholders serving successfully all the above-mentioned interests ${ }^{51}$ or that disclosure obligations will generate-on their own-long-term shareholder engagement ${ }^{52}$ being less than certain and outside the scope of this article, leaves the current SRD II rules in a 'conceptual limbo'. By attempting to inculcate an 'investor paradigm' shift, ${ }^{53}$ merging private and public aspects of the corporate governance role of institutional investors and their investment management, the SRD II becomes a normative source in open competitionin terms of persuasiveness and attractiveness-with pre-existing, national soft-law instruments, such as stewardship codes or principles, to which we now turn.

\subsection{The National Aspirations: The Case of National Stewardship Codes}

The shareholder stewardship provisions of the SRD II did not arrive in a normative gap. Rather, they added to a high-profile, pre-existing record of national standards for shareholder stewardship. ${ }^{54}$ Within Europe, four EU Member States, i.e. the UK, ${ }^{55}$ the Netherlands, ${ }^{56}$ Italy $^{57}$ and Denmark, ${ }^{58}$ as well as Switzerland ${ }^{59}$ and Norway ${ }^{60}$ had introduced measures to increase the level and quality of institutional shareholders' engagement with investee companies and to facilitate a shareholder

\footnotetext{
51 For a critical approach, see also Chiu (2019), p 126 (stating that 'the merging of "private shareholder conduct" with the expectations of institutions as socially-representative investors has created an ambivalent issue area whose nature remains unresolved').

52 Birkmose (2014).

53 Katelouzou (2017), p 140.

54 Currently stewardship codes or similar principles-based frameworks exist in twenty countries around the world. For a textual comparative analysis of stewardship codes, see Katelouzou and Siems (2021).

55 The first stewardship code was introduced by the UK Financial Reporting Council (FRC) in 2010 and it was revised in 2012 and again in 2019. For the most recent version see Financial Reporting Council, The UK Stewardship Code 2020, https://www.frc.org.uk/getattachment/5aae591d-d9d3-4cf4-814a-d14e1 56a1d87/Stewardship-Code_Final2.pdf. Accessed 4 December 2019.

56 In the Netherlands, a stewardship code was introduced in 2018 by Eumedion, an institutional investors' forum, to replace the 2011 Eumedion 10 Best Principles for Engaged Share-Ownership. See, further, the Dutch Stewardship Code (20 June 2018), https://www.eumedion.nl/en/public/knowledgenetwor k/best-practices/2018-07-dutch-stewardship-code-final-version.pdf. Accessed 4 December 2019.

57 In Italy, Assogestioni, an association of asset managers, adopted stewardship principles in 2013 and revised them in 2015 and 2016. For the latest version of the principles, see Assogestioni, Italian Stewardship Principles for the exercise of administrative and voting rights in listed companies (2016), https ://www.assogestioni.it/sites/default/files/docs/principi_ita_stewardship072019.pdf. Accessed 4 December 2019.

58 See the Danish Committee on Corporate Governance, Stewardship Code (November 2016), https:// corporategovernance.dk/sites/default/files/180116_stewardship_code.pdf. Accessed 4 December 2019.

59 In Switzerland, in 2013 Economiesuisse (a Swiss NGO representing the interests of the Swiss business community), associations of institutional investors, proxy advisers and regulatory authorities joined forces and published the 'Guidelines for institutional investors governing the exercising of participation rights in public limited companies', https://swissinvestorscode.ch/wp-content/uploads/2013/06/Richtlinie n_16012013_e.pdf. Accessed 4 December 2019.

60 The Norwegian stewardship principles introduced by the Norwegian Fund and Asset Management Association in 2003 and revised in 2012 are available (in Norwegian) at https://vff.no/assets/Bransjenor mer/Bransjeanbefalinger/Bransjeanbefaling-ut\%C3\%B8velse-av-eierskap.pdf. Accessed 4 December 2019.
} 
stewardship orientation among institutional investors, before the introduction of the SRD II.

These national stewardship codes originate from different issuers. In the UK and Denmark, the codes emanate from quasi-regulators, the Financial Reporting Council and the Danish Committee on Corporate Governance, respectively. ${ }^{61}$ The Swiss code has been a joint effort by private and public actors, ${ }^{62}$ whilst in Italy, The Netherlands, and Norway the stewardship codes are investor-led. This difference in authorship has some impact on the content and scope of the stewardship codes. ${ }^{63}$ The 2012 version of the UK Stewardship Code contains seven key principles ranging from the development and disclosure of an engagement policy to monitoring the investee companies and being prepared to escalate any stewardship activities, and from acting collectively with other investors where appropriate and exercising voting rights to disclosing voting policy and behaviour, avoiding conflicts of interests and reporting to beneficiaries. ${ }^{64}$ The 2012 UK code was overhauled in 2019 following serious criticism directed at the practicalities of exercising stewardship, including the questionable abilities and capacities of institutional investors and the extensive focus of the 2012 version on stewardship policies rather than on outcomes. ${ }^{65}$ The new 2020 UK code comprises twelve principles for asset owners ${ }^{66}$ and asset managers and six separate principles for service providers, including investment. ${ }^{67}$ The new stewardship principles are supported by reporting expectations which sometimes differ according to whether those applying the code are investing directly or indirectly. ${ }^{68}$

Despite its overhaul, the 2012 version of the UK code has left its mark firmly upon stewardship codes around the world. ${ }^{69}$ In Europe, the Danish Stewardship Code contains the same seven stewardship principles as its UK 2012 counterpart. $^{70}$ From the investor-led codes, the Dutch code incorporates the same seven stewardship principles as the UK and Danish codes with the addition of principles relating

\footnotetext{
61 But one should note that the UK Stewardship Code emanates from the Code on the Responsibilities of Institutional Investors, issued by the Institutional Shareholders' Committee (ISC). For the history of the UK code, see Katelouzou (2021).

62 The Swiss code has been published by Economiesuisse, the Government (Swiss Federal Office for Social Security), the Association of Swiss Pension Fund Providers, the Swiss Bankers Association and Ethos (the Swiss foundation for Sustainable Development).

63 See Katelouzou and Siems (2021) studying 41 stewardship codes and providing some empirical evidence that the nature of the issuer has an impact on the incorporation of some of the stewardship principles.

64 UK Stewardship Code 2012.

65 For a comprehensive analysis of the new code, see Katelouzou (2021).

66 The term 'asset owners' found in national stewardship codes is broadly similar to the term 'institutional investors' used by the SRD II.

67 Katelouzou (2021).

68 Ibid.

69 For empirical evidence on the diffusion of the UK stewardship principles across the world see Katelouzou and Siems (2021).

70 This similarity in the content may be explained by the fact that both the UK and Danish codes have been issued by quasi-regulators. For a comprehensive comparison between the UK and Danish codes, see Birkmose and Madsen (2021).
} 
to: (1) communication with other stakeholders where appropriate, ${ }^{71}$ (2) the need to consult the investee company before exercising the shareholder rights to submit a request for convening an extraordinary general meeting or put an item on the agenda of a general meeting, ${ }^{72}$ and (3) abstaining from voting in case of short positions and recalling share lending before voting. ${ }^{73}$ The Italian code consists of six principles which closely resemble the key aspects of its UK counterpart, ${ }^{74}$ but it incorporates elements that are strictly related to the Italian regulatory framework, including the slate voting system for the election of the management and supervisory board members and behind-the-doors dialogues. ${ }^{75}$

Both the Norwegian and Swiss codes are more a type of a "preliminary stewardship initiative' than a proper stewardship code. ${ }^{76}$ The Norwegian code is probably the most 'alien' of the investor-led codes as it solely focuses on the investment management aspects of stewardship incorporating selected references to the 2011 EFAMA's (European Fund and Asset Management Association's) 'code for external governance ${ }^{77}$ and Norwegian investment law (mostly related to securities funds). ${ }^{78}$ Finally, the Swiss code-despite its multiple issuers-is also limited in its content having its main focus on the exercise of voting rights by institutional investors. The Swiss code repeatedly refers to the interests of the clients (the ultimate beneficiaries) of institutional investors rather than responsible shareholding and has, therefore, been characterised as a 'watered-down' version of the 2012 version of the UK code. $^{79}$

Finally, in terms of their scope, the UK (2012), Danish, Dutch and Swiss codes apply to both asset owners and asset managers, while the Italian and Norwegian codes are aimed at asset managers. The limited scope of the Italian and Norwegian codes reflects the nature of the issuer which in both cases is an association of asset managers. On the other hand, the UK 2020 code has the widest scope comprising of principles not only for asset owners and asset manager but also for service providers.

Even though the national stewardship codes exhibit differences in authorship, scope and content, all but the Swiss code ${ }^{80}$ use the term 'stewardship' to encompass

\footnotetext{
71 Dutch Code, Principle 5.

72 Dutch Code, Principles 9 and 10.

73 Dutch Code, Principle 11.

74 Note that in the Italian code the principles of engagement and escalation are incorporated in a single principle (Principle 4).

75 Strampelli (2021).

76 Katelouzou and Siems (2021).

77 EFAMA, 'Code for External Governance: Principles for the Exercise of Ownership Rights in Investee Companies', Brussels, 6 April 2011, https://www.efama.org/Publications/Public/Corporate_Governance /11-4035\%20EFAMA\%20ECG_final_6\%20April\%202011\%20v2.pdf. Accessed 4 April 2020.

78 Mähönen et al. (2021). Due to its limited content, the Norwegian code has been characterised as a preliminary initiative rather than a code. See Katelouzou and Siems (2021).

79 Daeniker and Hertig (2021).

${ }^{80}$ Even though the Swiss code-being a preliminary initiative-does not use the term 'stewardship', its principles resemble many of the shareholder stewardship principles found in other codes (especially in relation to voting and disclosure). For cross-country differences in the principles of the stewardship codes, see Katelouzou and Siems (2021).
} 
the vision of the long-term institutional investor which is capable and willing to monitor the management of investee companies with the aim of promoting longterm value, whilst at the same time acting as a steward to safeguard the interests of its own beneficiaries and the economy as a whole. This 'stewardship ideal', also termed as an 'investor paradigm' for corporate law and corporate governance regulation, ${ }^{81}$ attempts to construe what appears to be an irreconcilable tension between value-enhancing shareholder engagement in corporate affairs aiming at improving corporate performance and portfolio returns for the end-investors, on the one hand, and accountability to a variety of constituents, ranging from end-investors to investee companies' shareholders and wider stakeholders, on the other hand, such as employees, creditors or environment, with the overall aim being the furtherance of aggregate social welfare. While the weight placed on the need to enhance accountability across the investment chain varies widely across the national stewardship codes, ${ }^{82}$ this tension between value-enhancing monitoring and accountability has been manifested in different ways across different asset owners and asset managers and different countries. ${ }^{83}$ But a common feature of all national stewardship codes is their soft, non-binding nature. Most of them are either completely voluntary (as in the case of the Norwegian and Swiss codes) or incorporate an expectation that the comply-or-explain approach will be followed on a voluntary basis (as in the case of the Danish, Dutch and Italian codes). Only the UK code has some coerciveness, as the apply-and-explain (comply or explain) approach of the UK 2020 (2012) code is mandatory for FCA-authorized asset managers. ${ }^{84}$

Overall, national stewardship codes and similar initiatives have managed, notwithstanding their soft, non-binding nature and other limitations relating to their narrow, national scope, ${ }^{85}$ to attract a substantial amount of market attention, especially among asset managers, ${ }^{86}$ and to trigger awareness of the need for responsible ownership within the investment chain. Sometimes these codes have been influenced by supranational developments, as is the case with the Italian and Norwegian codes which have been largely drafted on the basis of the EFAMA code. ${ }^{87}$ However, within this wider regulatory network of national and supranational stewardship soft-law norms, it needs to be acknowledged that the stewardship codes are part of broader national frameworks shaped within legal, market and cultural specificities.

\footnotetext{
81 Katelouzou (2017).

82 Compare, for instance, in this regard the UK 2020 code and the Swiss code.

83 See e.g. Klettner (2017).

84 Further on the enforcement parameters of stewardship codes, see Katelouzou and Sergakis (2020).

85 For a critical approach to stewardship codes, see, among others, Cheffins (2010); Reisberg (2015).

${ }^{86}$ Asset owners have been slower to embrace stewardship due to their business models. See, for instance, FRC/FCA (2019), p 25 (pointing out that 'while 68\% of asset owners have a stated policy on stewardship, only $37 \%$ set out their stewardship expectations in the mandates they give asset managers').

87 See further Katelouzou and Siems (2021).
} 


\subsection{The Broader National Stewardship Frameworks: Legal, Market and Cultural Specificities}

National shareholder stewardship frameworks are dependent on various national legal traits, including company law rules and investment management requirements (such as fiduciary duties) facilitating or impeding stewardship. ${ }^{88}$ National stewardship codes have been developed within well-established corporate governance frameworks and sometimes they specifically refer to national corporate governance codes as 'complementary counterparts' noting that shareholder stewardship can give force to the 'comply or explain' system upon which corporate reporting is based. ${ }^{89}$ In addition, shareholder stewardship interfaces with the position of institutional shareholders as minority shareholders. Company law rules are, therefore, a decisive factor that can facilitate or impede shareholder stewardship practices. Rules relating to shareholder voting rights and the conduct of annual general meetings, for instance, have been discussed extensively in the previous literature and many authors have pointed to the impact of such rules on shareholder engagement and shareholder activism. ${ }^{90}$ In the EU, shareholder protection has been at the top of the policy agenda since the 2003 Action Plan $^{91}$ and following the enactment of the SRD I many procedural aspects of exercising shareholder rights have been harmonized. ${ }^{92}$ But the SRD I has been criticised as falling short of harnessing the full potential of shareholder engagement, ${ }^{93}$ and there is still ample room for the preservation of national legal traits that may impede or promote shareholder engagement and stewardship orientation. ${ }^{94}$ For instance, in Germany section 54 of the Aktiengesetz (the German Corporation Act) allows shareholders to remain passive. Yet, it is debatable whether this 'right to remain passive' prohibits shareholder engagement. ${ }^{95}$ On other occasions, country-specific legal nuances may promote shareholder stewardship as is the case with the shareholder right to appoint minority directors and statutory auditors in Italy. Indeed, Strampelli has argued that minority directors are often appointed by collective engagement activities supported by Assogestioni, the issuer of the Italian stewardship code. These minority rights therefore play a key role in

\footnotetext{
88 On how law impacts the demand and supply side of the stewardship market, see Katelouzou (2021).

89 This is, for instance, the case with the UK Stewardship Code 2012 which states: 'The UK Corporate Governance Code identifies the principles that underlie an effective board. The UK Stewardship Code sets out the principles of effective stewardship by investors. In so doing, the Code assists institutional investors better to exercise their stewardship responsibilities, which in turn gives force to the "comply or explain" system' (p 1). For a detailed analysis of this broader stewardship framework in the UK, see Katelouzou (2021).

90 See e.g. Van der Elst (2010); Katelouzou (2015), pp 819-826.

91 European Commission, 'Action Plan on Modernising Company Law and Enhancing Corporate Governance-A Plan to Move Forward', COM(2003) 284.

92 Directive of the European Parliament and of the Council amending Directive 2007/36/EC as regards the encouragement of long long-term shareholder engagement and Directive 2013/34/EU as regards certain elements of the corporate governance statement [SWD(2014) 126,127,128 final].

93 E.g. Masouros (2010).

94 See e.g. Inci (2017), pp 145-146.

95 Ringe (2020).
} 
fostering the involvement of institutional shareholders in the corporate governance affairs of publicly listed companies in Italy. ${ }^{96}$

While both the nature and success of shareholder engagement depend decisively on shareholder rights, stewardship also has an important investment management aspect. ${ }^{97}$ The realisation of the envisaged stewardship role by institutional investors largely depends on the nature and character of investment management. Regulation plays a contributory part in shaping the incentives of institutional investors and asset managers to engage in stewardship activities. Çelik and Isaksoon have suggested, in a research paper for the Organisation for Economic Co-operation and Development (OECD), that the 'business model' of different institutional investors has an impact on the character and degree of shareholder engagement, ${ }^{98}$ and Chiu and Barker have examined the impact of regulatory obligations imposed on UK pension funds and retail collective investment schemes that impede engaged ownership. ${ }^{99}$ The Norwegian Stewardship Code, for instance, concentrates its focus on securities fund management companies and makes direct references to Norwegian legal specifications, such as the Norwegian Act on Securities Funds and the Securities Funds Regulation. ${ }^{100}$ While more research is still required on the investment management aspects of stewardship both at the national and supranational level, ${ }^{101}$ EU legislation has already addressed some general regulatory aspects of investment management. ${ }^{102}$ But despite these efforts, serious concerns still remain in relation to the asset managers' regulatory duties and their overall compliance stance. For instance, EFAMA has already evoked the lack of knowledge in respect of 'many country-specific nuances' and the difficulty that asset managers have in complying with national provisions. ${ }^{103}$ Finally, as the concept of shareholder stewardship is deeply intertwined with sustainability concerns, the way in which the sustainable behaviour of both companies

\footnotetext{
96 Strampelli (2021).

97 For the distinction between the corporate governance and investment management aspects of stewardship see Katelouzou (2019a) and (2021).

98 Çelik and Isaksson (2013), pp 93-114.

99 Barker and Chiu (2017).

100 Mähönen et al. (2021).

101 For such research in the UK context, see Katelouzou (2021).

102 See e.g. Directive 2009/65/EC of the European Parliament and of the Council of 13 July 2009 on coordination of laws, regulations and administrative provisions relating to undertakings for collective investment in transferable securities (UCITS) [2009] OJ L 302/32, Arts. 7, 68, 69 and 73; Directive 2010/43/EU of 1 July 2010 implementing Directive 2009/65/EC of the European Parliament and of the Council as regards organisational requirements, conflicts of interests, conduct of business, risk management and content of the agreement between a depositary and a management company [2010] OJ L 176/42, Arts. 13, 17-18 and 20-23; Directive 2001/61/EU of the European Parliament and of the Council of 8 June 2011 on Alternative Investment Fund Managers and amending Directive 2003/41/EC and 2009/65/EC and Regulations (EC) No. 1060/2009 and (EU) No. 1095/2010 [2019] OJ L 174/1, Arts. 9, 12, 22-24; Commission Delegated Regulation (EU) No. 231/2013 of 19 December 2012 supplementing Directive 2011/61/EU of the European Parliament and of the Council with regard to exemptions, general operating conditions, depositaries, leverage, transparency and supervision [2012] OJ L 83/1.

103 See EFAMA, 'Towards Capital Markets' Long-Termism: Revised Shareholder Rights Directive', Brussels, 7 June 2019, https://www.efama.org/Pages/Submitted\%20after\%202018-03-12T16 $\% 2022 \% 2007 /$ Towards-capital-markets'-long-termism---revised-shareholder-rights-directive.aspx. Accessed 4 December 2019.
} 
and investors is regulated can potentially have an impact on stewardship activities. ${ }^{104}$ Here the differences across Member States are substantial, ${ }^{105}$ but the EU is making significant steps to harmonize the non-financial reporting requirements for both companies and investors and to expand directors' and investors' duties to account for ESG factors. 106

Market infrastructure also becomes critical for shareholder stewardship. Leaving aside the structures and incentives of the fund management industry, ${ }^{107}$ the ownership structure of investee companies can affect the likelihood and success of shareholder stewardship practices and it would therefore be utopic to anticipate the accomplishment of the generic SRD II objectives at the national level in a uniform way. Member States vary significantly in the ownership concentration and types of shareholders at the company level. ${ }^{108}$ Previous literature has elaborated how different ownership structures impact engagement practices and shareholder activism more generally. ${ }^{109}$ For instance, in countries with dispersed ownership, such as the UK, shareholder engagement and more aggressive forms of shareholder activism (expressed by both traditional and alternative institutional investors) is a much more frequent phenomenon. ${ }^{110}$ On the other hand, in countries with concentrated ownership, such as Germany and Italy, such activism, while initially not developed due to the presence of opposing controlling shareholders, now becomes more and more notable. ${ }^{111}$ Lastly, in the latter category, we also find countries, such as Sweden and Finland, whose predominantly controlling shareholders also impede shareholder engagement. ${ }^{112}$ But the general rise of institutional investors in European equity markets, even where controlled companies are still predominant, creates enabling conditions for the development of shareholder stewardship. ${ }^{113}$ Another key market parameter for shareholder stewardship, as Katelouzou points out, is the substantial differences in pension systems across Europe and the varying emphasis on state-funded pension schemes. The shift from defined benefit to defined contribution arrangements in countries like the UK had a dramatic impact on the direct

\footnotetext{
104 Katelouzou (2019a).

105 See e.g. the European Commission Impact Assessment of 24 May 2019 SWD(2018) 264 (final), 24-25 and 153-157 (overviewing the cross-country differences on ESG disclosure requirements).

106 European Commission, 'Action Plan: Financing Sustainable Growth; Proposal for a regulation of the European Parliament and of the Council on disclosures relating to sustainable investments and sustainability risks and amending Directive (EU) 2016/2341' (2018), COM/2018/354 final.

107 On this see Barker and Chiu (2017).

108 For recent data, see De La Cruz et al. (2019).

109 See e.g. Van der Elst (2010), p 57; Katelouzou (2015).

110 See e.g. Katelouzou (2013); Fichtner (2015).

111 See e.g. Ringe (2015), p 429. There is, however, a variation in these countries. In Germany, shareholder activism in general and hedge fund activism specifically has flourished in recent years due to the growing dispersion in the ownership structure. But in Italy, hedge fund activism has flourished due to strong minority shareholder rights even though concentrated ownership structures do persist. On the different triggering factors, see Erede (2013).

112 For an overview of these and other (non-EU) countries, see Fenwick and Vermeulen (2018).

113 Chiu and Katelouzou (2017), p 133
} 
allocations by pension funds to equities. This in turn has a negative effect on the demand for shareholder stewardship from pension funds. ${ }^{114}$

Finally, the overall institutional context, ${ }^{115}$ including cultural specificities, can play a decisive role in the development of good shareholder stewardship practices. Licht's analysis of cultural distance and 'foreignness ${ }^{116}$ deserves specific attention here. Indeed, corporate governance characteristics are related to value emphases and cognitive elements attached to national frameworks. ${ }^{117}$ This also explains the resistance of some frameworks to adapt to changes, perpetuating their own cultural values over time. ${ }^{118}$ In the case of shareholder stewardship, a cultural aversion to shareholder engagement in corporate affairs is noticeable among Member States that share a network-oriented or stakeholder-oriented corporate governance tradition, often associated with the cultural dimensions of egalitarianism, the ideal of a voluntary commitment to promoting the welfare of others. ${ }^{119}$ The role of national élites in resisting any exogenous modification of traditional norms or rules that may undermine their own position is also important here. ${ }^{120}$ Indeed, in some countries such as France, institutional investors and asset managers are seen as a potential threat to the corporate establishment when actively engaging with their investee companies. ${ }^{121}$ Additionally, the 'proper' tools of shareholder engagement are perceived differently across the EU, depicting cultural preferences in terms of communication routes. ${ }^{122}$

To conclude this section, for shareholder stewardship, like any other legal norms, to operate as designed there must exist a widely shared social norm of stewardship abidingness. At the same time, shareholder stewardship norms and rules are shaped and exercised differently in different national contexts depending upon legal nuances, market structures, cultural traditions and other contingent factors. Without such supporting social norms and local institutions, shareholder stewardship cannot

\footnotetext{
$\overline{114}$ See further Katelouzou (2021).

115 On the embeddedness of corporate governance in different social contexts, see e.g. Granovetter (1985).

116 Licht (2004).

117 Ibid., p 198. On the importance of culture and ideology in influencing a country's choice of a corporate legal system, see Bebchuk and Roe (1999), p 168. On the difficulty in achieving a commonly shared view of corporations in Europe (that also indirectly influences, in our view, the perception and meaningful adoption of stewardship norms) see Wymeersch (2002), p 230; Davies and Hopt (2013).

118 Inglehart and Baker (2000). Hermes also denotes a striking lack of preparedness in relation to the SRD II rules at the national level, an assertion that shows the persisting barriers to the gradual acceptance of stewardship norms and to the need for a gradual absorption of the 'top-down' regulation: Hermes (2019).

119 Further on how egalitarianism affects corporate governance and investment, see Siegel, Licht and Schwartz (2011). For empirical evidence linking culture to corporate governance systems, see Breuer and Salzmann (2012).

120 For the roles of élites in cultural reproduction which generate social continuity without entirely impeding corporate governance reform, see Maclean, Harvey and Press (2006).

121 See for example the recent Woerth Report in France criticising shareholder activism: https://www. assemblee-nationale.fr/15/rap-info/i2287.asp. Accessed 22 February 2020.

122 For instance, in the UK behind the scenes negotiations seem to be the preferred method of investors' engagement with companies. See further Becht et al. (2009).
} 
operate effectively especially when it is imported in a top-down fashion as is the case with the transposed SRD II stewardship-related rules.

\section{National Transposition Trends: A Puzzle in Search of an Explanation}

\subsection{A Literal and Minimalistic Transposition}

As mentioned above, the SRD II is a minimum harmonization directive which aims to create a common framework whilst leaving room for divergent national specification. ${ }^{123}$ Although lower standards of shareholder engagement and associated disclosures are not allowed, Member States can introduce higher standards of shareholder stewardship and customize the EU rules according to local circumstances. ${ }^{124}$ In most cases, however, Member States have largely copied Article 3g of SRD II without adapting the EU policy to domestic circumstances. ${ }^{125}$ Representative examples of such a literal and minimalistic transposition can be found in Germany, ${ }^{126}$ Greece, ${ }^{127}$ Luxembourg, ${ }^{128}$ Portugal, ${ }^{129}$ Sweden, ${ }^{130}$ and Spain. ${ }^{131}$ Belgium has also been a

\footnotetext{
123 See Sect. 2.1 above.

124 Earlier Europeanization research refers to situations where Member States implement EU law in a non-literal way—e.g. Steunenberg (2007)—or go beyond minimum requirements as 'over-implementation' or 'gold-plating'-e.g. Falkner et al. (2005). More recent studies explore 'customization' along two dimensions, i.e. density and restrictiveness. See Thomann and Zhelyazkova (2017).

125 Despite the expiry of the transposition deadline of 10 June 2019, not all Member States have transposed Art. 3g. For example, Greece transposed all of the SRD II rules by 10 June 2019, except for the provisions related to disclosure and engagement duties (Art. 3g-3i) that only became subject to public consultation in March 2020: see Law 4548/2018 'Reform of the law of Sociétés Anonymes', Government Gazette Vol. A, No. 104/June 13, 2018. For information on the national transposition measures see: https ://eur-lex.europa.eu/legal-content/EN/NIM/?uri=CELEX:32017L0828. Accessed 6 April 2020.

126 Entwurf eines Gesetzes zur Umsetzung der zweiten Aktionärsrechterichtlinie (ARUG II): section $134 \mathrm{~b}$.

127 Nó

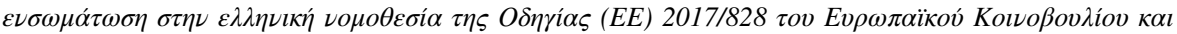

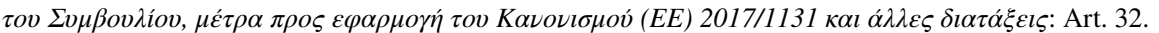

128 Loi du ler août 2019 modifiant la loi modifiée du 24 mai 2011 concernant l'exercice de certains droits des actionnaires aux assemblées générales de sociétés cotées aux fins de transposer la directive (UE) 2017/828 du Parlement européen et du Conseil du 17 mai 2017 modifiant la directive 2007/36/CE en vue de promouvoir l'engagement à long terme des actionnaires: Art. $1^{\mathrm{er}}$ sexies.

129 Anteprojeto de diploma de transposição da diretiva relativa ao exercício de certos direitos dos acionistas de sociedades cotadas, no que se refere aos incentivos ao envolvimento dos acionistas a longo prazo: Art. $251 .^{\circ} \mathrm{B}$.

130 Art. $3 \mathrm{~g}$ has been transposed into a number of laws in Sweden: 'Lagen om tryggande av pensionsutfästelse m.m. (1967:531)' 10 e $\S-10$ h § ; 'Lagen om värdepappersfonder (2004:46)', $17 \mathrm{~h} \S-17 \mathrm{k} \S$; 'Lagen om värdepappersmarknaden (2007:528)', 20 a §-20 d §; 'Försäkringsrörelselagen (2010:2043)', 13 a $\$-13$ d §; 'Lagen om förvaltare av alternativa investeringsfonder (2013:561)', 27 a $\S-8 \mathrm{~d} \S$.

131 Anteproyecto de Ley por la que se modifica el texto refundido de la Ley de Sociedades de Capital, aprobado por el Real Decreto Legislativo 1/2010, de 2 de julio, y otras normas financieras, para adaptarlas a la Directiva (UE) 2017/828 del Parlamento Europeo y del Consejo, de 17 de mayo de 2017, por la que se modifica la Directiva 2007/36/CE en lo que respecta al fomento de la implicación a largo plazo de los accionistas: Arts. 67 bis and 79 bis.
} 
literal transposer of the SRD II provisions opting for what it calls a 'faithful' transposition of a minimum harmonization directive. ${ }^{132}$ While a literal transposition can imply a high degree of compliance with EU policies, in the context of shareholder stewardship one may question the degree of fit or 'misfit" ${ }^{133}$ between the SRD II rules and existing national soft or hard laws, market structures and cultural traditions. It is therefore surprising that the same literal implementation was followed even by Member States with pre-SRD hard-law provisions that imposed more onerous transparency requirements on institutional investors. For instance, France ripped off the previous requirement for asset managers to justify to institutional shareholders the reasons for which they had decided not to exercise their voting rights. The current version of this article has now removed this additional requirement incorporating a literal and minimalistic transposition of Article 3g (SRD II) and specifying that the details of disclosure items will be provided by a decree by the Conseil d'État. ${ }^{134}$ It will thus be interesting to see if this tighter pre-SRD II domestic requirement will be permanently removed despite the discretion of Member States to go beyond the necessary minimum standards.

A literal transposition of the SRD II shareholder stewardship requirements has taken place even in Member States with pre-existing soft-law stewardship codes, such as in The Netherlands ${ }^{135}$ and Italy. ${ }^{136}$ In Denmark Article $3 \mathrm{~g}$ was also transposed in a literal and minimalistic way despite the slightly wider scope of the Danish transposition rules which also apply to some sui generis Danish funds. ${ }^{137}$

Finally, in the UK the transposition of Article $3 \mathrm{~g}$ has been bifurcated on the basis of the nature of the regulatees. For asset managers and insurers, the Financial Conduct Authority (FCA), the responsible authority for the implementation of the relevant SRD II provisions, chose to copy paste Article 3g, with the only distinctiveness

\footnotetext{
132 Proposition de loi portant transposition de la directive (UE) 2017/828 du Parlement européen et du Conseil du 17 mai 2017 modifiant la directive 2007/36/CE en vue de promouvoir l'engagement à long terme des actionnaires, et portant des dispositions en matière de société et d'association: Session extraordinaire, Chambre des représentants de Belgique, 4 October 2019, DOC 55 0553/001, 5.

133 On the concept of 'misfit' or 'adaptational pressure' in transposing EU directives, see e.g. Treib (2003).

134 See Art. L.533-22 Code monétaire et financier prior to the SRD transposition (Loi $n^{\circ} 2019-486$ du 22 mai 2019 relative à la croissance et la transformation des entreprises, Loi PACTE).

135 Wijziging van Boek 2 van het Burgerlijk Wetboek, de Wet op het financieel toezicht en de Wet giraal effectenverkeer ter uitvoering van Richtlijn 2017/828/EU van het Europees Parlement en de Raad van 17 mei 2017 tot wijziging van Richtlijn 2007/36/EG wat het bevorderen van de langetermijnbetrokkenheid van aandeelhouders betreft (PbEU 2017, L 132): Art. 5:87c and 5:87d.

136 Decreto Legislativo 10 maggio 2019, n. 49: Attuazione della direttiva 2017/828 del Parlamento europeo e del Consiglio, del 17 maggio 2017, che modifica la direttiva 2007/36/CE per quanto riguarda l'incoraggiamento dell'impegno a lungo termine degli azionisti: Art. 124-quinquies.

137 See Lov nr. 369 af 09/04/2019 om andring af selskabsloven, lov om kapitalmarkeder, lov om finansiel virksomhed og forskellige andre love (Gennemforelse af andringer i aktionarrettighedsdirektivet om tilskyndelse til langsigtet aktivt ejerskab), § 3, No 3 and 4, § 4, No 3, § 5, No 2, § 6 No 2, § 7, No 1, and $\S 8$, No 1. On the wider scope of the Danish transposed rules, see Birkmose and Madsen (2021).
} 
being the expanded geographical scope of the UK transposed rules to investments in shares traded outside the EU. ${ }^{138}$ The FCA considers this non-prescriptive approach as providing flexibility to asset owners and asset managers ${ }^{139}$ to meet the stewardship requirements depending on their business models and investment mentalities. ${ }^{140}$ For trustees and occupational pension schemes, the UK Pensions Regulator is the authority that transposed Article $3 \mathrm{~g}$ of the SRD II by introducing new disclosure stewardship obligations in June 2019. ${ }^{141}$ These complement the regulations introduced in 2018 to require pension trustees to set out in their Statements of Investment Principles (SIP) their policies on financially material considerations, including ESG, and the shareholder stewardship (including monitoring and voting) of scheme investments. $^{142}$

Overall, we find that a literal and minimalistic transposition of Article $3 \mathrm{~g}$ of the SRD II took place both in Member States with and without pre-existing stewardship codes. While such a literal transposition of EU directives is a frequent phenomenon, ${ }^{143}$ previous research has shown that where literal transposition takes place at the expense of a careful adaptation to the specific circumstances in each Member State, shortcomings in enforcement and application are common. ${ }^{144}$ In the specific context of shareholder stewardship, this literal and minimalistic transposition is likely to reduce the attractiveness of shareholder stewardship in the eyes of market actors. This is because asset owners (or institutional investors in the SRD II jargon) and asset managers will mostly focus on ensuring boilerplate compliance with the minimalistic and generic transposed rules in order to avoid liability. But before trying to find a solution to this suboptimal regulatory outcome, let us consider some explanations for this apparent 'transposition puzzle'.

\subsection{In Search of Transposition Rationales}

The literal, minimalistic and a-contextual transposition of Article $3 \mathrm{~g}$ runs counter to what would be predicted based on the foregoing elaboration of the legal, market and cultural specificities of national shareholder stewardship markets. ${ }^{145}$ It is also surprising to see literal transposition trends in countries with pre-SRD II soft stewardship codes or preliminary stewardship initiatives, which create excellent conditions

\footnotetext{
${ }^{138}$ For UK insurers and reinsurers, see Senior Management Arrangements, Systems and Controls (SYSV) sourcebook 3.4 SRD Requirements. For UK asset managers, see Conduct of Business Sourcebook (COBS) 2.2B SRD requirements.

139 Meaning MIFID investment firms, alternative investment fund managers (AIFMs) (excluding small AIFMs), UCITS management companies, self-managed UCITS funds and FCA-regulated insurers.

140 FCA (2019), p 10.

141 The Occupational Pension Schemes (Investment and Disclosure) (Amendment) Regulations 2019.

142 The Pension Protection Fund (Pensionable Service) and Occupational Pension Schemes (Investment and Disclosure) (Amendment and Modification) Regulations 2018. On the stewardship framework in the UK, see Katelouzou (2021).

143 See e.g. Schimmelfenning and Sedelmeier (2007).

144 Falkner and Treib (2008).

145 See Sect. 2.3 above.
} 
for a tailored adaptation of EU policy to domestic circumstances. Leaving aside the general problems associated with the delayed and highly routinized transposition of EU directives, ${ }^{146}$ we identify several reasons for this trend.

First, Article $3 g$ juridifies new normative features of shareholder stewardship obligations with which most of the Member States are not familiar. The requirement of developing and implementing an engagement policy is not something with which national regulatory authorities and regulatees are instinctively familiar. This argument is reinforced if one examines the transposition of other SRD II provisions. Unlike the stewardship-related engagement and disclosure provisions, the transposition of the more familiar SRD II rules relating to 'say on pay' or related party transactions has been tailored at the national level in a way that depicts the idiosyncrasies and features of different company law traditions. ${ }^{147}$ Research on EC implementation has identified the degree of institutional and policy fit or misfit between EU harmonized rules and existing, national institutional and regulatory features as one of the central factors that determine the implementation success. ${ }^{148}$ Here, there is a related argument about path dependence and the lock-in effects or 'stickiness' of pre-existing norms which create formidable pressures for continuity. ${ }^{149}$ If one applies this argument of pre-existing national institutions, norms and rules that persist change in the context of SRD II, then it becomes clear that Member States should customize rather than copy harmonized rules that relate to issues closely attached to their respective legal traditions or that have been traditionally subject to hard (and maybe soft) law at the national level to allow for the continuity of the differentiating national rules. ${ }^{150}$ To put it in another way, the more outlandish the harmonized rule is, as is the case with the stewardship-related provisions of the SRD II, the less likely the tailored transposition will be.

Another reason explaining the literal and minimalistic transposition of Article $3 \mathrm{~g}$ is the lack of a strong market demand for shareholder stewardship in Europe. ${ }^{151}$ Despite the increasing institutionalisation of public equity across Europe, ownership differences persist. A characteristic example is Germany where the market demand for stewardship from local institutional investors is not as strong as in the UK. It is well documented that German public equity, long seen as being dominated by

\footnotetext{
146 See e.g. Berglund, Gange and Van Waarden (2006).

147 For instance, the highly contentious issue of 'say on pay' that, similar to stewardship, is dependent on national legal traditions, has allowed room for tailored transposition with various options offered by Art. 9a and 9b SRD II. Some Member States (France) provide for a binding shareholder vote on both the remuneration policy and report, others (the UK, Poland, Romania and Spain) provide for a binding vote on the remuneration policy and an advisory one on the remuneration report, and still others (Austria, Belgium, Germany and Finland) provide for an advisory one on both matters.

148 For an overview of this literature, see Falkner et al. (2005), pp 15-17.

149 The literature here is voluminous. See, among others, DiMaggio and Powell (1991); Fligstein and Freeland (1995); Klausner (1995); Bebchuk and Roe (1999).

150 This is evident in the area of related party transactions (RPTs). Here some Member States have maintained their own legal traditions in their entirety making use of the various flexibility safeguards being provided by Art. 9c SRD II. This flexibility was the outcome of a compromise, following the Commission's initial proposals that were considerably stricter. For an overview, see Enriques and Tröger (2018).

151 Further on the demand side of stewardship see Katelouzou and Micheler (2021).
} 
German blockholders, has been increasingly institutionalized over the past 20 years mainly due to the advent of foreign investors. ${ }^{152}$ While this institutionalization may increase the demand for stewardship in the future (especially from foreign investors) and trigger the development of soft stewardship initiatives, at present local players, such as German pension funds, are not as developed as in other countries and therefore a demand for shareholder stewardship from German investors is lacking. ${ }^{153}$ This may explain why there is no appetite for a tailored transposition of the SRD II in Germany. Also, institutional investors vary widely in their ability to evaluate the performance of their asset manager in terms of stewardship activities. In the UK, for instance, despite the efforts by the FCA to strengthen investors' stewardship capability, institutional investors are still not taking their stewardship obligations seriously enough. ${ }^{154}$ Investor stewardship abilities and capacities are even less in other Member States with no pre-SRD II stewardship norms (such as Germany). Another issue affecting the demand side of stewardship is the compatibility of the duties (often fiduciary in nature) that institutional investors, particularly pension trustees, owe to their beneficiaries. There has been much debate in recent years over the extent to which such duties require investors to maximize investment returns. ${ }^{155}$ In some countries, such as the UK, it is now clear that ESG considerations and stewardship are permissible. ${ }^{156}$ But in other countries, this debate is still unresolved. ${ }^{157}$ To all these, one needs to add that benefits from stewardship activities are not easily quantified. ${ }^{158}$ This weakens even further the demand for shareholder stewardship. On the lack of such a demand at the national level, there are no lower-level (market) actors, such as institutional investors or their associations, to lobby for customized rules or even resist the literal adoption of the SRD II stewardship-related provisions. ${ }^{159}$

Finally, the literal and minimalistic transposition trend can be explained in light of the acknowledgement that more flexible tools, such as stewardship codes or other related principles, may be better suited to inculcate shareholder stewardship practices to which the next section is devoted.

\footnotetext{
$\overline{152}$ For data, see De La Cruz, Medina and Tang (2019).

153 Ringe (2020).

154 See e.g. Tilba and Reisberg who provide evidence that only a few occupational (local) authority pension funds in the UK have realised the aspirations of investor stewardship and engagement: Tilba and Reisberg (2019).

155 See e.g. Sandberg (2013).

156 Katelouzou (2021).

157 PRI and others' Fiduciary Duty in the 21st Century (2019), https://www.unepfi.org/wordpress/wpcontent/uploads/2019/10/Fiduciary-duty-21st-century-final-report.pdf. Accessed 31 March 2020.

158 On the mixed evidence in relation to the financial benefits of stewardship see Katelouzou and Micheler (2021).

159 On the role of institutional 'veto players' see generally Tsebelis (2002).
} 


\section{The Enduring Importance of National Stewardship Codes or Principles/Guidelines}

\subsection{The Benefits of Stewardship Codes: Flexibility, Compliance, Legitimacy and Signalling}

The attributes of soft law, including its non-binding character, flexibility and gradual nudging capacity towards meaningful compliance, are well discussed. ${ }^{160}$ Stewardship codes or principles/guidelines have all these features, but in addition they apply to investors (signatories) that voluntarily regard stewardship as compatible with their investment management practices. This is an additional attractiveness point for stewardship codes (as compared with corporate governance codes, for instance) as they can stimulate compliance not only from domestic market actors but also from foreign ones; indeed, foreign actors may want to become signatory parties of such initiatives for reputational purposes and to signal their proximity to a specific local market and clients for the expansion of their activities and clientele. By contrast, the SRD II applies to all the institutional investors and asset managers as defined in Article 1(2)(e) SRD II and this has been transposed in national regimes, and not only to signatory parties. Also, the requirement to develop, disclose and implement an engagement policy under the transposed SRD II rules even though it operates on a comply-or-explain basis, it still has strong coerciveness: the regulatees have to comply or explain with regard to the transposed national rule. ${ }^{161}$ Both features point out the stronger SRD II presumption with regard to the relevance of shareholder engagement for investment management. ${ }^{162}$ By contrast, soft stewardship codes and principles/guidelines by offering flexibility and malleability in the shaping of their content and expectations from signatory parties can promote tailored stewardship practices and inculcate stewardship to national frameworks that have not progressed significantly in that area or have not witnessed an institutionalized effort to shape stewardship norms.

Second, national soft-law stewardship initiatives have increased the familiarity of market actors with stewardship practices and in some cases their awareness and compliance readiness with regard to the SRD II stewardship-related rules. Indeed, anecdotal evidence on the disclosure practices of signatory parties to national stewardship codes reveal that they have been more familiarized with the SRD II transposed rules, while remaining open to additional levels of transparency that derive from their adherence to national codes or principles. ${ }^{163}$ A recent survey of European

\footnotetext{
160 See e.g. Sergakis (2013).

161 See also Sect. 2.1 above.

162 See also Chiu and Katelouzou (2017).

163 See, for instance, the engagement policy statement of Lazard Asset Management, a signatory to the UK Stewardship Code, https://www.lazardassetmanagement.com/docs/-m0-/88455/SRDIIEngagement Policy_en.pdf. Accessed 4 December 2019. Also see the statement from the Danish Corporate Governance Committee highlighting the beneficial impact of the Danish Stewardship Code on the gradual familiarity that investors gained with the transposed SRD II rules: https://corporategovernance.dk/udfas ning-af-anbefalinger-aktivt-ejerskab. Accessed 24 February 2020.
} 
institutional investors' awareness and readiness for the SRD II by Hermes found that $79 \%$ of the Dutch investors surveyed were aware of the SRD II as opposed to $42 \%$ in Spain. ${ }^{164}$ The survey also reported that Spain has the lowest understanding and compliance readiness of any country studied pointing to the lack of a stewardship code in place. ${ }^{165}$ Yet, the relationship between the pre-existence of national stewardship codes, on the one hand, and the awareness of and compliance readiness with regard to the SRD II stewardship-related rules, on the other, is not a linear one and notable exceptions exist. For instance, Italian institutional investors are reported as having low awareness and compliance readiness with regard to the SRD II despite the presence of stewardship principles directed to asset managers since $2016 .{ }^{166}$ This may be regarded as confounding the positive attributes of soft stewardship codes, but market and cultural traits can explain, to some degree, the Italian case. While there has been a growing interest in voting in recent years, Italian investors tend to disregard longterm shareholder engagement and shareholder stewardship as an investment tool. ${ }^{167}$ It is also noteworthy that the limited scope of the Italian code, which applies only to asset managers (and not to institutional investors), may also explain why Italian investors appear to be less familiar with and less compliance-ready to apply the SRD II stewardship-related tools. ${ }^{168}$ Nevertheless, there is some evidence that the national demand for soft-law initiatives is currently shifting in Italy: in 2020, three institutional investors (Inarcassa, Cassa Forense and Enpam) formed the Association of Responsible Investors (Assodire) with the aim, inter alia, of defining a best practice policy for their members and issuing a judgement so as to align shareholder stewardship activities with such policy. Assodire is also open to more institutional investors who may want to join this voluntary initiative. During the same period, various Italian institutional investors announced the formation of a similar network so as to better exercise their shareholder stewardship activities and to aspire to their own high standards via the increase of awareness, research studies, training courses and assistance to institutional investors in their activities. ${ }^{169}$

While the potential of stewardship codes and similar principles/guidelines to promote familiarity and compliance with shareholder stewardship norms and rules surely depends on their scope and traction in national contexts, other stewardship norm setters (public or quasi-public authorities, industry associations etc.) have a crucial role to play in enabling multiple points of reference for the improvement of

\footnotetext{
164 Hermes (2019).

165 Ibid.

166 Ibid.

167 Ibid. See also Strampelli (2021).

168 For instance, some institutional investors have been focusing primarily on complying with IORPs' rules (provided by Directive (EU) 2016/2341 of the European Parliament and of the Council of 14 December 2016 on the activities and supervision of institutions for occupational retirement provision (IORPs) [2016] OJ L 354/37) demonstrating thus a much lower degree of awareness of SRD II rules. 'Engagement fondi, frenato dal mandato', Etica News, 19 March 2020.

169 See for example, the 'Centro di tutela dei diritti degli azionisti istituzionali' created by Associazione Italiana per la Previdenza Complementare (Assoprevidenza) in collaboration with the Consiglio Nazionale dei Dottori Commercialisti e degli Esperti Contabili (CNDCEC), available at https://assoprevidenza. it/chi-siamo/.
} 
best practices and the achievement of high shareholder stewardship standards. ${ }^{170}$ At the transnational level, the EFAMA Stewardship Code $^{171}$ and the International Corporate Governance Network (ICGN) Global Stewardship Principles ${ }^{172}$ provide, respectively, EU and international outlooks in relation to market expectations on best shareholder stewardship practices. But while the EFAMA code aims to serve as 'a European reference document' for asset managers seeking to comply with the SRD II stewardship-related provisions, national stewardship norms are better suited to support institutional investors and asset managers aiming to comply more meaningfully with the transposed SRD II provisions as they are more sensitive to localized legal, market and cultural traits.

Third, there is a legitimacy argument in favour of the preservation and development of soft stewardship codes and similar initiatives. By facilitating compliance with the SRD II-related stewardship rules, national soft stewardship codes can help institutional investors to seek legitimacy from both (quasi-)public regulators and other markets actors. In other words, the transposed rules, similar to soft-law stewardship codes, promote interaction between market actors within the investment chain as well as between these actors and society (ranging from the ultimate beneficiaries to various stakeholders affected by the corporate economy). ${ }^{173} \mathrm{By}$ obliging such actors to disclose their engagement policies and investment practices, the transposed SRD II rules inadvertently create a 'neo-institutional' dimension that drives investors towards the need to acquire legitimacy within society, ${ }^{174}$ looking beyond rational economic behaviour that only relates to their profits. But the literal and minimalistic transposition of the SRD II stewardship-related rules is likely to have a knock-on effect on these legitimacy attributes. This is because the informational quality of the shareholder engagement statements imposed by the SRD II is expected to be poor following the literal and minimalistic transposition of the SRD II stewardship-related rules. Market actors, therefore, will endeavour to discover more meaningful (and sometimes additional) information arising from disclosures triggered by soft-law stewardship tools that often add informational elements that go beyond the SRD II, as is the case with the 2020 version of the UK Stewardship Code which puts an increasing emphasis on ESG factors and stewardship outcomes. ${ }^{175}$ This is why market actors support the introduction of post-SRD II stewardship codes, in countries such as Germany, so as to fill implementation gaps and to entice investors to produce more detailed policy statements and to avoid cursory

\footnotetext{
170 As is the case in Finland and Sweden: see Fenwick and Vermeulen (2018), p 33.

171 EFAMA, 'Stewardship Code: Principles for Asset Managers' Monitoring of, Voting in, Engagement with Investee Companies', https://www.efama.org/Publications/Public/Corporate_Governance/EFAMA \%20Stewardship\%20Code.pdf. Accessed 7 April 2020.

172 See https://www.icgn.org/sites/default/files/ICGNGlobalStewardshipPrinciples.pdf. Accessed 7 April 2020.

173 Möslein and Sørensen (2018).

174 On the concept of legitimacy in this framework, see Scott (2001b).

175 Of course, this does not necessarily suggest that the information quality of the statements to national stewardship codes will always be superior in quality compared to the information generated by SRD IIrelated disclosures. On the disclosure quality of the statements of the signatories to the UK Stewardship Code, see Katelouzou (2021).
} 
reporting. ${ }^{176}$ Having the unique capacity to go beyond a formalistic compliance with the literally transposed SRD II rules, soft stewardship codes and similar initiatives can provide distinctive benefits for signatory parties to become more open and discursive towards other actors through their stewardship statements. Additionally, this auxiliary informational exposure is safeguarded in its flexibility and malleability in the absence of formal public sanctions, contrary to what is provided as an option by Article $14 \mathrm{~b}$ of the SRD II. ${ }^{177}$

Finally, adherence to soft-law stewardship codes may strengthen the signalling effect that stewardship statements produced in compliance with Article $3 \mathrm{~g}$ of the SRD II have on ultimate beneficiaries, other investors and boards of investee companies, ${ }^{178}$ and stimulate the demand side of the stewardship market. ${ }^{179}$ For instance, ultimate beneficiaries have become increasingly interested in responsible, long-term investment and the impact of the adopted stewardship strategy, such as engagement, upon the investment portfolio. The information contained in shareholder stewardship statements, especially when a single statement is used to comply with both soft and hard-law stewardship norms, ${ }^{180}$ often goes beyond the items provided by Article $3 \mathrm{~g}$ of the SRD II and can therefore amplify the signalling effect of stewardship to the market. This should gradually increase the incentives of institutional investors to become signatory parties of a stewardship code or set of principles/guidelines and reap reputational benefits. Other investors can also use the disclosed information generated by stewardship codes to distinguish engagement strategies that contribute to the improvement of corporate governance from others that have a more shortterm focus. This is especially important in the context of activist campaigns when the support of fellow investors is sought by activist funds that aim to collectively change corporate governance matters in investee companies. ${ }^{181}$ Boards of directors can also find the information contained in stewardship statements useful when they engage with investors as adherence to stewardship codes can entice them towards a greater availability to initiate dialogue so as to clarify a series of issues. ${ }^{182}$

A final point to be raised is that different soft stewardship instruments from different issuers and different content may present their own advantages for different purposes. For instance, some codes can allow a more targeted focus on the achievement of specific outcomes within the national context. Take, for instance, the examples of the Swiss or Norwegian codes, which focus solely on shareholder voting and investment management, respectively, or the Italian code which only applies to Italian asset managers. Such codes, better described as preliminary stewardship

\footnotetext{
176 Hermes (2019), p 4.

177 Art. 14b of the SRD II enables Member States to provide for effective proportionate and dissuasive measures and penalties for violations of its transposed provisions into national law. On this issue, see Katelouzou and Sergakis (2020).

178 Alvaro, Maugeri and Strampelli (2019), p 58.

179 Katelouzou (2021).

180 See the text accompanying n. 215 below.

181 On collective shareholder engagement, see e.g. Micheler (2013); Katelouzou (2021).

182 Alvaro, Maugeri and Strampelli (2019), p 59.
} 
initiatives, ${ }^{183}$ despite their limited nature can still instil a common denominator of shareholder stewardship in frameworks that are still in their infancy or are still indecisive about the regulatory approach that needs to be adopted. If such initiatives are seen as a 'normative laboratory' that is able to inaugurate a basic-yet initially static-framework, they may well prepare the ground for the multiplication of more 'extended' stewardship codes at the national level ${ }^{184}$ or even a gradual transition to the latter. ${ }^{185}$ While there is only some very limited evidence on the impact of pre-SRD II stewardship norms on investment practices, ${ }^{186}$ preserving and evolving stewardship codes or principles as well as multiplying such soft-law norms across the EU will support the functionality of the wider 'symbiosis' with the harmonized rules.

\subsection{An Emerging Symbiosis of SRD II Rules and Soft Law Norms}

We have already seen that shareholder stewardship norms occupy a highly complex and interconnected regulatory space—or better 'spaces" ${ }^{187}$ — dominated by various public, quasi-public and market actors. In Member States with pre-existing stewardship codes, public or quasi-public authorities, investor associations or other private groups have already been influential in shaping stewardship norms and practices. With the transposition of SRD II, the engagement and disclosure elements of shareholder stewardship have been juridified and have moved away from a purely self-regulatory environment. ${ }^{188}$ As a result, in Member States with pre-SRD II stewardship norms we are already witnessing a progressive symbiosis of the transposed SRD II rules with domestic soft law instruments. In this section we support the expansion of such a symbiotic relationship across the EU advancing the claim that soft-law codes or principles are innovative norm-generating mechanisms.

Starting with the UK, the FCA and the FRC (a quasi-public agency responsible for the UK Stewardship Code) ${ }^{189}$ have engaged in joint-up policy thinking on stewardship following the enactment of SRD II. ${ }^{90}$ The current shareholder stewardship regulatory framework in the UK features the transposed (by the FCA and Pension Regulator) rules as the minimum regulatory baseline for shareholder stewardship

\footnotetext{
183 Katelouzou and Siems (2021).

184 For example, the EFAMA Code has already influenced the creation of national codes in the EU and may continue to do so in other Member States, while purporting to serve as an auxiliary tool for market actors to comply with different national codes.

185 This gradual evolution of stewardship codes is part of the general evolution of legal norms. For an application of systems theory and new institutional approaches within corporate governance, see generally Deakin and Carvalho (2011).

186 Becht, Franks and Wagner (2019) (using proprietary data to study the investment stewardship practices of Aberdeen Standard Investments, a UK-active asset manager).

187 On the multiple regulatory spaces or political economies of corporate law production, see Katelouzou and Zumbansen (2020).

188 On the juridification or legalization of stewardship, see Chiu and Katelouzou (2017), p 143.

189 In 2020, the FRC will be replaced by the Audit, Reporting and Governance Authority (ARGA) which will be a public body.

190 FRC/FCA (2019).
} 
actions, with the 2020 version of the UK Stewardship Code promoting higher stewardship standards that go beyond the minimum SRD II rules. ${ }^{191}$ The FCA explicitly recognises the role of other stewardship norm-setters and allows regulatory space for industry participants, such as investors' associations, or other stakeholders to develop additional guidance to aid interpretation and promote the comparability of stewardship disclosures. ${ }^{192}$ The need for such a coordinated industry approach has been emphasized in the case of voting disclosures. ${ }^{193}$

Another sign of innovation in the development of soft-law norms is the expansion of the stewardship-related regulatory agenda in the UK. While the original rationale behind the introduction of shareholder stewardship in the UK was mostly related to the financial crisis, 'absentee landlords' and blatant corporate governance failures, the revised 2020 stewardship code shows elements of a gradual detachment from such law-and-economics arguments and a gradual embracing of overarching public priorities related to the shaping of a sustainable-focused stewardship framework. ${ }^{194}$ The evolution of the UK stewardship principles from the preliminary Institutional Shareholders' Committee (ISC) 1991 statement to the 2020 FRC code demonstrates that the continuous interaction of market actors with constantly evolving soft-law norms will not simply increase familiarity and compliance with the harmonized SRD II rules but will, most importantly, allow for the overall improvement of stewardship standards and practices. ${ }^{195}$ But we need to acknowledge that the UK benefits from a market infrastructure that has traditionally favoured openness to foreign capital and market actors, thereby providing a highly prolific framework for the emergence and furtherance of market-driven initiatives in the area of shareholder stewardship. The same levels of stewardship demand and market infrastructure, as we have seen above, are largely absent in other Member States that seem to be resisting the idea of introducing soft stewardship codes or principles/guidelines within their national framework. ${ }^{196}$

Signs of a fruitful symbiosis and normative innovation can also be found in Italy. In the public consultation launched by the CONSOB (the Italian public authority for regulating securities markets and in charge of implementing and enforcing the transposed SRD II rules) for the implementation of the SRD II, the role of Assogestioni, the representative association of Italian asset managers and the issuer of the Italian Stewardship Code, has been accredited as the normative precursor to the transposed SRD II rules and as a key factor facilitating compliance without subjecting the regulatees to a significant increase in compliance burdens and costs. ${ }^{197}$ Most importantly, the Società per lo sviluppo del Mercato dei Fondi Pensione (Mefop Spa), ${ }^{198}$

\footnotetext{
191 See also Sect. 2.2 above.

192 FCA (2019), p 14.

193 Ibid.

194 This has been described as a movement towards 'enlightened stewardship'. See further Katelouzou (2021).

195 Ibid.

196 See Sect. 2.3 above.

197 CONSOB (2019), p 31.

198 See https://www.mefop.it/site/chi-siamo/chi-siamo. Accessed 24 February 2020.
} 
a company founded by the Italian Ministry of Economy and Finance (which still remains its majority shareholder) and capital participation by various asset owners (e.g. pension funds, insurance companies etc.) with the aim being to develop welfare means via research, interpretation and the communication of welfare norms, aims to occupy some regulatory space in a symbiotic relationship with the SRD II rules. In March 2020, Mefop sent a questionnaire to its members to gauge the levels of awareness concerning the SRD II stewardship-related rules. ${ }^{199}$ In October $2020,{ }^{200}$ Mefop shared with its members the opportunity to create a set of stewardship guidelines. In contrast with most stewardship codes or principles across the globe, ${ }^{201}$ the envisaged guidelines will not require any commitment in terms of adherence and are aimed to function as a common reference point which will increase dialogue between institutional investors and investee companies, increase the awareness of SRD II stewardship-related rules, educate Italian institutional investors and fill the gap left by the Assogestioni's stewardship code. The proposed multiplication of soft-law stewardship norms in Italy by Mefop is reflective of the malleable character of soft-law stewardship initiatives that aim to help market actors to better absorb top-down regulation, such as the SRD II rules, and guide them towards meaningful compliance and higher levels of stewardship practices. Such initiatives are even more important when top-down regulation is not customized to national circumstances, as is the case with the SRD II transposed rules. We should thus see such innovation as an example that needs to be followed across the EU.

Another interesting case of a symbiotic relationship between national stewardship norms and the transposed SRD II stewardship-related rules is the Dutch Stewardship Code which was revised in 2018 following the transposition of the SRD II. The Dutch code is the only stewardship code so far that makes direct references to the SRD II. The preamble to the Dutch code is indicative of its multi-level normative nature. The code: (1) 'builds and supersedes' the 2011 stewardship code; (2) 'incorporates' the semi-hard stewardship obligations for asset owners and asset managers stemming from Article 3g of the SRD II; (3) 'incorporates the best practices of the Dutch Corporate Governance Code that apply to asset owners and asset managers'; and (4) 'contains a number of additional principles as a result of evolving stewardship expectations' ${ }^{202}$ Importantly, principle 1 of the Dutch code (which incorporates Article $3 g$ of the SRD II) chooses the term 'stewardship policy', rather than 'engagement policy' that is used in the SRD II. ${ }^{203}$ This is because 'engagement' is considered to be only a facet of the broader concept of stewardship. ${ }^{204}$ The Dutch code also extends beyond the SRD II and includes principles relating to communication with relevant stakeholders (Principle 5) or borrowing and lending shares (Principle 11).

\footnotetext{
199 'Mefop studia un Stewardship Code per la previdenza', Etica News, 5 March 2020.

200 Mefop, Tavolo di lavoro 'Investitori previdenziali alla prova della Direttiva Shareholder Rights II', 1 October 2020.

201 Further on stewardship enforcement, see Katelouzou and Sergakis (2020).

202 Dutch Code, p 2.

203 Dutch Code p 6.

204 Dutch Code, p 7. See also Katelouzou (2021).
} 
While in the UK, Italy and the Netherlands we have seen signs of a fruitful symbiosis between soft national stewardship norms and the transposed SRD II stewardship-related rules, Denmark has taken the perhaps surprising decision to abolish pre-existing soft-law norms on the transposition of SRD II rules. On 28 January 2020, the Danish Committee on Corporate Governance announced, in agreement with the Minister of Business Affairs, that it will discontinue the applicability of the Danish Stewardship Code. The Committee recognized the beneficial role that the Danish code has played so far in preparing market actors to follow the transposed SRD II rules and ensuring openness on how institutional investors manage assets. But the Committee considered that there is now an overlap between the semi-hard obligations set forward by the SRD II and the soft Danish code and, therefore, it decided to abolish the code. ${ }^{205}$ It is interesting to note that the Danish code was introduced whilst the SRD II was imminent and the Danish Committee foresaw that the implementation of the SRD II could overlap with the soft stewardship framework. $^{206}$ Indeed, the scope of the Danish Code and the transposed rules is almost identical-with the exception of some sui generis Danish investors. ${ }^{207}$ In terms of content, all principles of the Danish code, apart from Principle 3 on escalating activity, are now found in the transposition framework. Birkmose and Madsen have argued that escalation is an 'implicit part of shareholder engagement' and should therefore be reflected in future policies on active ownership required by the Danish transposed rules despite that lack of a specific reference. ${ }^{208}$ To that one can add that the escalation principle has been the least well-perceived principle of the inaugural UK Stewardship Code, ${ }^{209}$ and is not incorporated in Article $3 \mathrm{~g}$ of the SRD II.

But what does the Danish example tell us about the future of soft shareholder stewardship norms? We find the marginalisation of soft-law norms, as is the case in Denmark, to be a regulatory faux pas for the following reasons. By depriving the market of a soft stewardship code, institutional investors and asset managers will have less-if no-guidance about what should be included in the engagement policies provided by the SRD II. Indeed, the norm-setters of soft stewardship codes have a unique capacity - due to their proximity to and experience of the market- to develop and maintain an ongoing dialogue with the regulatees, and thereby to nudge and guide actors towards meaningful compliance. Moreover, in the absence of a soft stewardship code or related principles/guidelines, market actors will depend on a future revision of the SRD II rules to see any evolution or amendments applicable to their shareholder stewardship obligations. Such a revision may take longer than the much more frequent revision of soft-law norms that can depict new challenges or changes in the investment management models affecting stewardship practices. Lastly, the obligation to comply with the literal and minimalistic SRD II rules, in the

\footnotetext{
205 Corporate Governance, 'Udfasning af Anbefalinger for aktivt Ejerskab', 28 January 2020, https:// corporategovernance.dk/udfasning-af-anbefalinger-aktivt-ejerskab. Accessed 24 February 2020.

206 Birkmose and Madsen (2021).

207 See also Sect. 2.2 above.

208 Birkmose and Madsen (2021).

209 For empirical evidence on the relatively limited diffusion of this principle, see Katelouzou and Siems (2021).
} 
absence of accompanying tailored soft stewardship norms, will accentuate meaningless compliance trends since market actors will not have a flexible point of reference to disclose their strategies but will be conscious of the perils of coming across as non-compliant in a strict framework and hence reluctant to be more transparent. Birkmose and Madsen are optimistic, however, and argue that this abolition is not synonymous with the 'culmination of Danish stewardship'. ${ }^{210}$ Rather, they suggest that evolution can come from the incorporation of soft stewardship-related obligations in the Danish Corporate Governance Code, such as a duty by the board of directors to engage with institutional shareholders. ${ }^{211}$ Irrespective of whether stewardship-related norms will operate through the means of a standalone stewardship code, a corporate governance code or any other standards, guidelines, rules, codes of best practices or codes of conduct, the key message is clear: soft law in the area of shareholder stewardship can nudge market actors towards higher standards of stewardship and can act as a continuous driving force to promote compliance with the literal and minimalistic national rules that have transposed the SRD II.

This can provide food for thought and facilitate a debate on the merits of soft shareholder stewardship norms in Member States that have not created or testified to the development of soft law initiatives in the area of shareholder stewardship. Sweden is a representative example here. The Swedish Investment Fund Association revised its 2002 shareholder engagement guidelines for 'fund management companies' (asset managers) in May 2019, following the literal and minimalistic transposition of the SRD II rules. ${ }^{212}$ The guidelines specifically state that they 'have been adapted to shareholder engagement legislation which [...] implements' the SRD II. ${ }^{213}$ The guidelines significantly expand the statutory requirements in relation to the content of the shareholder engagement policy adding the following principles: (1) 'the fund management company's principles regarding its own participation in the work of nomination committees'; (2) 'how questions concerning inside information are handled in relation to the shareholder engagement'; (3) 'the situations in which the fund management company acts in the companies in which the fund owns shares, and the fund management company's escalation procedures'; (4) whether voting advisers are used; (5) 'the fund management company's principles for stock lending and how they are applied in order to perform the engagement where appropriate, particularly at general meetings of the companies that have issued shares that are included in the fund', and (6) 'other principles applied by the fund management company that are of material significance for the shareholder engagement'.

The Swedish development of innovative shareholder stewardship guidelines confirms that national law can provide more tailored solutions to local contexts. In addition, the incorporation of such customized solutions in a soft code of conduct developed by a domestic investor association underscores the importance of

\footnotetext{
210 Birkmose and Madsen (2021).

211 Ibid.

212 See https://www.fondbolagen.se/globalassets/regelverk/guidelines--code-of-conduct/guidelines-forfund-management-companies-shareholder-engagement.pdf. Accessed 4 April 2020.

213 Ibid., p 2.
} 
market demand and local institutional investor support so as to ensure good stewardship practices and support meaningful compliance with the SRD II transposed rules. Any future symbiotic relationship between soft stewardship codes or principles/guidelines and the transposed SRD II rules depends essentially upon the role of local investors' associations. Such investor associations and other multi-stakeholder and supranational forums ${ }^{214}$ can instil good shareholder stewardship practices through continuous dialogue amongst investors and standard setters and the shaping of collaborative activity pathways. Institutional investors that will actively invest resources, provide high-quality disclosure and meaningfully engage with asset managers will thus be of crucial importance in furthering the success of the national normative agenda. ${ }^{215}$

Overall, our analysis shows that the operability of the literal and minimalistic SRD II shareholder stewardship rules crucially depends on other soft stewardship norms (stewardship codes or principles/guidelines or any other related initiative included in corporate governance codes, best practice standards or codes of conduct) tailored to the specific national contexts. However, it needs to be acknowledged that the symbiosis of multiple stewardship frameworks (especially when these do not entirely overlap) may create some confusion for institutional investors and asset managers that adhere to all of them. For instance, in the UK there is now a partial overlap between the disclosure requirements under the FCA's Conduct of Business Sourcebook (COBS) that transposed Article 3g (SRD II) and reporting under the UK 2020 Stewardship Code. For instance, matters to be included in the engagement policy of COBS 2.2B.6 overlap with Principles 3, 9, 10 and 12 of the UK Stewardship Code which deal with conflicts of interests, engagement, collaboration with other investors and the exercise of shareholder rights, respectively. ${ }^{216}$ However, there is no real clarity as to the interaction between the two. Indeed, the FCA provides no Handbook guidance or any other templates on how insurers and asset managers can implement the transposed requirements. ${ }^{217}$ The FCA, however, leaves open the option for asset managers to report in a single document to both the COBS disclosure and the UK Stewardship Code, and requests asset managers to consider whether the disclosures they provide under the code are sufficient to meet the reporting imposed under the transposed rules. ${ }^{218}$ But this is not a clear option in other Member States with pre-existing stewardship codes, such as Italy or

\footnotetext{
214 See for example, the US Investor Stewardship Group (https://isgframework.org), the Japanese Institutional Investors Collective Engagement Forum (https://www.iicef.jp/en/), the British Local Authority Pension Fund Forum (https://www.lapfforum.org) and the Council of Institutional Investors (https:// www.cii.org). Similarly, see the role of EFAMA at the EU level that has already inspired the creation of national soft-law norms, such as the Italian Stewardship Principles.

215 See also Hermes (2018).

216 This overlap is recognised by the FCA itself. See FCA (2019), p 14.

217 On the implications of this overlap see, further, Katelouzou (2021).

218 FCA (2019), p 14. See e.g. Aberdeen Standard Investments Voting Rights Policy, which consists of a single statement for both the UK Stewardship Code and the SRD II transposed provisions due to the additional nudging of the UK code: https://www.aberdeenstandard.com/docs?editionId=bfcb3d9c-0a6e4e14-8eb2-26ee56d3a45d. Accessed 17 February 2020. Note that this statement was published in July 2019 and this is why it refers to the 2012 version of the UK Stewardship Code.
} 
the Netherlands. Another key challenge for the symbiosis between the SRD II rules and soft shareholder stewardship norms lies in the collective shaping of a normative framework of 'culturally compatible" ${ }^{219}$ stewardship at industry and national levels that acknowledges national traits while leaving space for both harmonized minimum standards and tailored practices to be introduced to the stewardship market. Of course, a series of adaptation limits are present here. For Member States with no pre-SRD soft stewardship norms, such as Germany, cognitive problems arise in relation to their reticence to accept shareholder stewardship as something malleable and constantly evolving. For other Member States with pre-SRD norms, such as Italy, other cognitive limitations may exist, such as the preoccupation of institutional investors with a more conventional perception of governance challenges that does not fully acknowledge currently emerging trends (e.g. ESG factors). But with the SRD II having been transposed in a literal and minimalistic way, this stewardship nexus can only be materialized with the continuous support and promotion of soft, tailored stewardship initiatives that can offer customization and meaning to the SRD II rules, while a minimum harmonization of shareholder stewardship has already been secured.

\section{Concluding Thoughts for an Optimal Symbiosis of Stewardship Norms}

In this article, we provided an original account of the rationale, the dynamics and the evolution of the EU policy towards long-term shareholder engagement within (or in the absence of) nationally embedded frameworks within which the broader concept of shareholder stewardship is currently emerging. Our key aim was to decipher the aspirations of the EU policy and the likelihood of its success. It was not our intention to deliver an all-encompassing analysis of the interaction between the SRD II transposed rules and the national legal frameworks. The complete image will only come into existence once market actors start implementing the semi-hard SRD II transposed rules or using them concomitantly with any pre-(or post-)SRD II softlaw stewardship norms.

Two key points stand out from our analysis. First, we denote the rather formalistic approach that has been adopted in the transposition of Article $3 \mathrm{~g}$ of the SRD II. Member States have largely copied the requirement for the development, disclosure and implementation of an engagement policy on the part of institutional investors and asset managers without allowing for a tailored and more meaningful customization according to national idiosyncrasies. Secondly, we highlight the positive attributes of soft shareholder stewardship norms, in terms of flexibility, enhanced familiarity and preparedness concerning the SRD II transposed rules, legitimacy and signalling as well as innovation, and on that basis we advocate the maintenance and multiplication of such soft-law norms. The proposed symbiotic shareholder stewardship framework, tailored to specific national circumstances, can offer market actors

219 Licht (2004), p 232. 
an operational normative space that is discursive, flexible and customized to evolving shareholder stewardship norms and practices.

To paraphrase Věra Jourová's statement: did we learn the lessons from the past? Unfortunately, the answer is: not very much. It is clear that the EU agenda focuses on responsible shareholder engagement, sustainable investment and long-term corporate growth. These are laudable policy objectives. But the means of achieving them-via the minimalist SRD II engagement and disclosure duties and the ensuing literal transposed rules-are not enough. The SRD II transposition cannot lead on its own to tailored shareholder stewardship practices and efficient outcomes without supporting soft-law stewardship initiatives (stewardship codes or principles/guidelines or any other related initiative included in corporate governance codes, best practice standards or codes of conduct). Simply put, moving on from focusing on short-term financial gain is not a simple task that can be solved with a single legal parameter. Nor can the literal and minimalistic national rules that transpose the SRD II stewardship-related provisions promote shareholder stewardship in Europe without any customization. Soft shareholder stewardship norms are therefore needed to go hand in hand with the transposed SRD II rules and support the emerging, but still to be concretely shaped, shareholder stewardship landscape.

Before we conclude it is important to emphasise that notwithstanding our critique on the literal transposition trends, we do not see this as necessarily suboptimal. Rather we argue that the lack of customization by the Member States has surprisingly left existing or future soft shareholder stewardship norms with a relatively large operational space (in terms of scope, content etc.), which is however not entirely autonomous. This is because soft-law shareholder stewardship can now operate to support and perhaps extend the minimum stewardship standards imposed by the transposed SRD II rules. On that basis, we argue that soft-law stewardship norms need to be multiplied across national markets so as to shape, together with the harmonized SRD II regime, a more flexible and tailored regulatory framework. The current examples of Italy and Sweden testify to the need to provide for experimental, less binding soft law tools to inculcate stewardship culture amongst investors and pave the way for more developments in this area. While much more must be done at the EU, national and industry level if we wish more fully to address the pressing challenges arising from the corporate governance role of institutional investors and asset managers, keeping the normative landscape diverse and open will surely help to promote shareholder stewardship in Europe.

Open Access This article is licensed under a Creative Commons Attribution 4.0 International License, which permits use, sharing, adaptation, distribution and reproduction in any medium or format, as long as you give appropriate credit to the original author(s) and the source, provide a link to the Creative Commons licence, and indicate if changes were made. The images or other third party material in this article are included in the article's Creative Commons licence, unless indicated otherwise in a credit line to the material. If material is not included in the article's Creative Commons licence and your intended use is not permitted by statutory regulation or exceeds the permitted use, you will need to obtain permission directly from the copyright holder. To view a copy of this licence, visit http://creativecommons.org/licen ses/by/4.0/. 


\section{References}

Alvaro S, Maugeri M, Strampelli G (2019) Investitori instituzionali, governo societario e codici di stewardship. Quad Giuridici Consob 19:1-78

Barker R, Chiu I (2017) Corporate governance and investment management. Edward Elgar, Cheltenham

Bebchuk LA, Roe MJ (1999) A theory of path dependence in corporate ownership and governance. Stanford Law Rev 52:127-170

Becht M, Franks J, Mayer C, Rossi S (2009) Returns to shareholder activism: evidence from a clinical study of the Hermes UK Focus Fund. Rev Financ Stud 22:3093-3129

Becht M, Franks J, Wagner HF (2019) Corporate governance through voice and exit. European Corporate Governance Institute-Finance Working Paper No 633/2019. https://ssrn.com/abstract=3456626. Accessed 4 Dec 2019

Berglund S, Gange I, Van Waarden F (2006) Mass production of law: routinization in the transposition of European directive: a sociological-institutionalist account. J Eur Public Policy 13:692-716

Birkmose H (2014) European challenges for institutional investor engagement-Is mandatory disclosure the way forward. Eur Company Financ Law Rev 2:214-257

Birkmose H, Madsen MB (2021) The Danish Stewardship Code-the past, the present and the future. In: Katelouzou D, Puchniak D (eds) Global shareholder stewardship: complexities, challenges and possibilities. Cambridge University Press, Cambridge. https://papers.ssrn.com/sol3/papers.cfm?abstr act_id=3533834. Accessed 22 Sep 2020

Breuer W, Salzmann AJ (2012) National culture and corporate governance. In: Boubaker S, Nguyen BD, Nguyen DK (eds) Corporate governance: recent developments and new trends. Springer, Berlin, pp 369-397

Çelik S, Isaksson M (2013) Institutional investors and ownership engagement. OECD J Financ Mark Trends 2:93-114

Cheffins BR (2010) The stewardship code's Achilles' heel. Mod Law Rev 73(6):1004-1025

Chiu I (2019) Private vs public enforcement of shareholder duties. In: Birkmose H, Sergakis K (eds) Enforcing shareholder duties. Edward Elgar, Cheltenham, pp 106-127

Chiu I, Katelouzou D (2017) From shareholder stewardship to shareholder duties: is the time ripe? In: Birkmose H (ed) (2017) Shareholders' duties. Kluwer Law International, Alphen aan den Rijn, pp $131-152$

Cioffi JW (2002) Restructuring 'Germany Inc'.: the politics of company and takeover law reform in Germany and the European Union. Law Policy 24:355-402

CONSOB (2019) Recepimento della Direttiva (UE) 2017/828 (Shareholder Rights Directive 2): Documento per la Consultazione. https://www.consob.it/web/consob/novita/-/asset_publisher/xMXdf deSuZFj/content/documendo-di-consultazione-del-31-ottobre-2019-recepimento-direttiva-share holder-rights/10194. Accessed 4 Dec 2019

Daeniger D, Hertig G (2021) Capitalist stakeholders: shareholder stewardship in Switzerland. In: Katelouzou D, Puchniak D (eds) Global shareholder stewardship: complexities, challenges and possibilities. Cambridge University Press, Cambridge

Dawson M (2009) Soft law and the rule of law in the European Union: revision or redundancy? EUI Working Paper RSCAS 2009/24. https://ssrn.com/abstract=1415003. Accessed 4 Dec 2019

De La Cruz A, Medina A, Tang Y (2019) Owners of the world's listed companies. OECD Capital Market Series, Paris. www.oecd.org/corporate/Owners-of-the-Worlds-Listed-Companies.htm. Accessed 4 Dec 2019

Davies P, Hopt KJ (2013) Boards in Europe: accountability and convergence. Am J Comp Law 61(2):301-376

Deakin S, Carvalho F (2011) System and evolution in corporate governance. In: Zumbansen P, Calliess GP (eds) Law, economics and evolutionary theory. Edward Elgar, Cheltenham, pp 111-130

DiMaggio PJ, Powell WW (1991) Introduction. In: DiMaggio PJ, Powell WW (eds) The new institutionalism in organizational analysis. Chicago University Press, Chicago, pp 1-38

Enriques L, Tröger TH (2018) The law and (some) finance of related party transactions: an introduction. European Corporate Governance Institute (ECGI) - Law Working Paper No 411/2018. https://ssrn. com/abstract=3214101. Accessed 4 Dec 2019

Erede M (2013) Governing corporations with concentrated ownership structure: an empirical analysis of hedge fund activism in Italy and Germany, and its evolution. Eur Company Financ Law Rev 10(3):328-393 
Falkner G, Treib O (2008) Three worlds of compliance or four? The EU-15 compared to new Member States. J Common Mark Stud 46(2):293-313

Falkner $\mathrm{G}$ et al (2005) Complying with Europe: EU harmonisation and soft law in the Member States. Cambridge University Press, Cambridge

FCA (2019) Proposals to promote shareholder engagement: Feedback to CP19/7 and Final Rules' Policy Statement, PS19/13

Fenwick M, Vermeulen E (2018) Institutional investor engagement: how to create a 'stewardship culture'. Lex Research Topics in Corporate Law \& Economics Working Paper No 2018-1; TILEC Discussion Paper No 2018-006, pp 14-18. https://ssrn.com/abstract=3098235. Accessed 4 Dec 2019

Fichtner J (2015) Rhenish capitalism meets activist hedge funds: blockholders and the impact of impatient capital. Compet Change 19:336-352

Fligstein N, Freeland R (1995) Theoretical and comparative perspectives on corporate organization. Ann Rev Sociol 21:21-43

FRC/FCA (2019) Building a regulatory framework for effective stewardship. Discussion Paper DP19/1:25

Granovetter M (1985) Economic action and social structure: the problem of embeddedness. Am J Sociol 91:481-510

Hancher L, Moran M (1989) Organizing regulatory space. In: Hancher L, Moran M (eds) Capitalism, culture and regulation. Clarendon Press, Oxford, pp 148-172

Hermes (2018) Statement on the draft act on the transposition of the amended shareholder rights directive (EU) 2017/828. https://www.bmjv.de/SharedDocs/Gesetzgebungsverfahren/Stellungna hmen/2019/Downloads/11302018_Stellungnahme_Hermes_ARUG-II.pdf?_blob=publicatio nFile\&v=2. Accessed 4 Dec 2019

Hermes (2019) Shareholder rights directive: a step towards sustainable capitalism. https://www.herme s-investment.com. Accessed 4 Dec 2019

Hertig G, McCahery JA (2006) Optional rather than mandatory EU company law: framework and specific proposals. Eur Company Financ Law Rev 4:341-362

Hopt KJ (2015) Corporate governance in Europe: a critical review of the European Commission's Initiatives on Corporate Law and Corporate Governance. N Y Univ J Law Bus 12:139-213

Horn L (2011) Regulating corporate governance in the European Union. Palgrave Macmillan, London

Inci S (2017) Shareholder engagement: Chancen, Risiken und Kompatibilität mit der deutschen Corporate Governance. Nomos, Baden-Baden

Inglehart R, Baker WE (2000) Modernization, cultural change, and the persistance of traditional values. Am Sociol Rev 65:19-51

Kallifatides M, Nachemson-Ekwall S (2016) Awakening giants? The politically contested modification of institutional investors. Corp Gov 16:278-294

Katelouzou D (2013) Myths and realities of hedge fund activism: some empirical evidence. Va Law Bus Rev 7:459-511

Katelouzou D (2015) Worldwide hedge fund activism: dimensions and legal determinants. Univ Pa J Bus Law Rev 17:789-860

Katelouzou D (2017) Reflections on the nature of the public corporation in the era of shareholder activism and shareholder stewardship. In: Choudhury B, Petrin M (eds) Understanding the company: corporate governance and theory. Cambridge University Press, Cambridge, pp 117-144

Katelouzou D (2019) Shareholder stewardship: a case of (re)embedding institutional investors and the corporation? In: Sjåfjell B, Bruner CM (eds) Cambridge handbook of corporate law, corporate governance and sustainability. Cambridge University Press, Cambridge, pp 581-595

Katelouzou D (2019b) Regulating shareholder engagement in Europe: from hard to soft law and never back (?). Working Paper, EURAM 2019 Conference paper

Katelouzou D (2021) Institutional shareholders and corporate governance: the path to enlightened stewardship. Cambridge University Press, Cambridge (forthcoming)

Katelouzou D, Klettner A (2021) Sustainable finance and stewardship: unlocking stewardship's sustainability potential. In: Katelouzou D, Puchniak D (eds) Global shareholder stewardship: complexities, challenges and possibilities. Cambridge University Press, Cambridge. https://ssrn.com/ abstract=3578447. Accessed 22 Sep 2020

Katelouzou D, Micheler E (2021) Stewardship in the UK: the demand side. In: Katelouzou D, Puchniak D (eds) Global shareholder stewardship: complexities, challenges and possibilities. Cambridge University Press, Cambridge. https://papers.ssrn.com/sol3/papers.cfm?abstract_id=37042 58. Accessed 22 Sep 2020 
Katelouzou D, Sergakis K (2020) Enforcement of shareholder stewardship. In: Katelouzou D, Puchniak D (eds) Global shareholder stewardship: complexities, challenges and possibilities. Cambridge University Press, Cambridge. https://papers.ssrn.com/sol3/papers.cfm?abstract_id=35642 66. Accessed 22 Sep 2020

Katelouzou D, Siems M (2021) The global diffusion of stewardship codes. In: Katelouzou D, Puchniak D (eds) Global shareholder stewardship: complexities, challenges and possibilities. Cambridge University Press, Cambridge. https://ssrn.com/abstract=3616798. Accessed 22 Sep 2020

Katelouzou D, Zumbansen P (2020) The new geographies of corporate law production. University of Pennsylvania International Law Review (forthcoming). https://ssrn.com/abstract=3575009. Accessed 22 Sep 2020

Klausner M (1995) Corporations, corporate law and networks of contracts. Va Law Rev 81:757-852

Klettner A (2017) The impact of stewardship codes on corporate governance and sustainability. N Z Bus Law Q 23:259-275

Licht AN (2004) Legal plug-ins: cultural distance, cross-listing, and corporate governance reform. Berkeley J Int Law 22:195-239

Maclean M, Harvey C, Press J (2006) Business elites and corporate governance in France and the UK. Palgrave Macmillan, London

Mähönen J, Sjafjell B, Mee M (2021) Stewardship Norwegian-style: fragmented and state-dominated (but not without potential?). In: Katelouzou D, Puchniak D (eds) Global shareholder stewardship: complexities, challenges and possibilities. Cambridge University Press, Cambridge. https:// ssrn.com/abstract $=3635359$. Accessed 22 Sep 2020

Masouros P (2010) Is the EU taking shareholder rights seriously?: An essay on the impotence of shareholdership in corporate Europe. Eur Company Law 7:195-203

Micheler E (2013) Facilitating investor engagement and stewardship. Eur Bus Organ Law Rev $14: 29-56$

Möslein F, Sørensen KE (2018) Nudging for corporate long-termism and sustainability? Regulatory instruments from a comparative and functional perspective. Columbia J Eur Law 24(2):391-454

Myners P (2009) Record of speech made to the Association of Investment Companies. https://webar chive.nationalarchives.gov.uk/20091207163737/https://hm-treasury.govuk/speech_fsst_21040 9.htm. Accessed 4 Dec 2019

Pacces AM (2018) Shareholder activism in the CMU. In: Busch D, Avgouleas E, Ferrarini F (eds) Capital markets union in Europe. Oxford University Press, Oxford, pp 507-525

Reisberg A (2015) The UK Stewardship Code: on the road to nowhere? J Corp Law Stud 15(2):217-253

Ringe G (2015) Changing law and ownership patterns in Germany: corporate governance and the erosion of Deutschland AG. In: Hill J, Thomas RS, Beasley JS (eds) Research handbook on shareholder power. Edward Elgar, Cheltenham, pp 404-438

Ringe G (2020) Stewardship and shareholder engagement in Germany. European Corporate Governance Institute-Law Working Paper No 501/2020. https://ssrn.com/abstract=3549829. Accessed 22 Sep 2020

Sandberg J (2013) (Re-)Interpreting fiduciary duty to justify socially responsible investment for pension funds. Corp Gov Int Rev 21:436-446

Schimmelfennig F, Sedelmeier U (2007) Candidate countries and conditionality. In: Graziano P, Vink MP (eds) Europeanization: new research agendas. Palgrave Macmillan, London, pp 88-101

Scott C (2001a) Analysing regulatory space: fragmented resources and institutional design. Public Law 00:283-305

Scott RW (2001b) Institutions and organizations, 2nd edn. Sage Publications, Thousand Oaks

Sergakis K (2013) The UK Stewardship Code: bridging the gap between companies and institutional investors. Rev Juridique Thémis 47:109-154

Siegel JI, Licht AN, Schwartz SH (2011) Egalitarianism and international investment. J Financ Econ 102:621-642

Strampelli G (2021) Institutional investor stewardship in Italian corporate governance. In: Katelouzou D, Puchniak D (eds) Global shareholder stewardship: complexities, challenges and possibilities. Cambridge University Press, Cambridge

Steunenberg B (2007) A policy solution to the European Union's transposition puzzle: interaction of interests in different domestic arenas. West Eur Politics 30:23-49

Thomann E (2015) Customizing Europe: transposition as bottom-up implementation. J Eur Public Policy 22:1368-1387 
Thomann E, Zhelyazkova A (2017) Moving beyond (non-)compliance: the customization of European Union policies in 27 countries. J Eur Public Policy 24:1269-1288

Tilba A, Reisberg A (2019) Fiduciary duty under the microscope: stewardship and the spectrum of pension fund engagement. Mod Law Rev 82(3):456-487

Treib O (2003) EU governance, misfit, and the partisan logic of domestic adaptation: an actor-centered perspective on the transposition of EU Directives. EUSA 8th Biennial International Conference, Nashville, Tenessee. https://www.ihs.ac.at/publications/pol/TreibPartisanLogic20 03.pdf. Accessed 22 Sep 2020

Tsebelis G (2002) Veto players: how political institutions work. Princeton University Press, Russell Sage Foundation, New York, Princeton

Van der Elst C (2010) The influence of shareholder rights on shareholder behavior. Corp Finance Capital Mark Law Rev 1:50-62

Wymeersch E (2002) Convergence or divergence in corporate governance patterns in Western Europe? In: McCahery JA, Moerland P, Raaijmakers T, Renneboog L (eds) Corporate governance regimes: convergence and diversity. Oxford University Press, Oxford, pp 230-250

Publisher's Note Springer Nature remains neutral with regard to jurisdictional claims in published maps and institutional affiliations.

\section{Affiliations}

\section{Dionysia Katelouzou $^{1}\left[\right.$ Konstantinos Sergakis $^{2}$ (])}

Konstantinos Sergakis

Konstantinos.Sergakis@glasgow.ac.uk

Dionysia Katelouzou

Dionysia.Katelouzou@kcl.ac.uk

1 Dickson Poon School of Law, King's College London, London, UK

2 School of Law, University of Glasgow, Glasgow, UK 